University of Nebraska - Lincoln

DigitalCommons@University of Nebraska - Lincoln

USDA Forest Service / UNL Faculty Publications U.S. Department of Agriculture: Forest Service -National Agroforestry Center

2011

\title{
Using hyperspectral imagery to estimate forest floor consumption from wildfire in boreal forests of Alaska, USA
}

\author{
Sarah A. Lewis \\ Rocky Mountain Research Station, sarahlewis@fs.fed.us \\ Andrew T. Hudak \\ Rocky Mountain Research Station, ahudak@fs.fed.us \\ Roger Ottmar \\ Pacific Northwest Research Station, rottmar@fs.fed.us \\ Pete Robichaud \\ USFS Rocky Mountain Research Station, probichaud@fs.fed.us \\ Leigh B. Lentile \\ University of Idaho, Iblentil@sewanee.edu \\ See next page for additional authors
}

Follow this and additional works at: https://digitalcommons.unl.edu/usdafsfacpub

Lewis, Sarah A.; Hudak, Andrew T.; Ottmar, Roger; Robichaud, Pete; Lentile, Leigh B.; Hood, Sharon M.; Cronan, James B.; and Morgan, Penelope, "Using hyperspectral imagery to estimate forest floor consumption from wildfire in boreal forests of Alaska, USA" (2011). USDA Forest Service / UNL Faculty Publications. 197.

https://digitalcommons.unl.edu/usdafsfacpub/197

This Article is brought to you for free and open access by the U.S. Department of Agriculture: Forest Service -National Agroforestry Center at DigitalCommons@University of Nebraska - Lincoln. It has been accepted for inclusion in USDA Forest Service / UNL Faculty Publications by an authorized administrator of DigitalCommons@University of Nebraska - Lincoln. 


\section{Authors}

Sarah A. Lewis, Andrew T. Hudak, Roger Ottmar, Pete Robichaud, Leigh B. Lentile, Sharon M. Hood, James B. Cronan, and Penelope Morgan 


\title{
Using hyperspectral imagery to estimate forest floor consumption from wildfire in boreal forests of Alaska, USA
}

\author{
Sarah A. Lewis ${ }^{\mathrm{A}, \mathrm{F}, *}$, Andrew T. Hudak ${ }^{\mathrm{A}, *}$, Roger D. Ottmar ${ }^{\mathrm{B}}$, \\ Peter R. Robichaud', Leigh B. Lentile ${ }^{\mathrm{C}}$, Sharon M. Hood ${ }^{\mathrm{D}}$, \\ James B. Cronan ${ }^{\mathrm{B}}$ and Penny Morgan ${ }^{\mathrm{E}}$ \\ A USDA Forest Service, Rocky Mountain Research Station, Forestry Sciences Laboratory, \\ 1221 S Main Street, Moscow, ID 83843, USA. \\ ${ }^{B}$ USDA Forest Service, Pacific Northwest Research Station, Pacific Wildland Fire Sciences \\ Laboratory, 400 N 34th Street, Suite 201, Seattle, WA 98103, USA. \\ ${ }^{\mathrm{C}}$ Department of Forestry and Geology, The University of the South, 735 University Avenue, \\ Sewanee, TN 37383, USA. \\ DUSDA Forest Service, Rocky Mountain Research Station, Fire Sciences Laboratory, \\ 5775 US Highway 10 W, Missoula, MT 59808, USA. \\ E Department of Forest Resources, University of Idaho, 6th and Line Street, \\ Moscow, ID 83843, USA. \\ FCorresponding author. Email: sarahlewis@fs.fed.us \\ *Authors have contributed equally.
}

\begin{abstract}
Wildfire is a major forest disturbance in interior Alaska that can both directly and indirectly alter ecological processes. We used a combination of pre- and post-fire forest floor depths and post-fire ground cover assessments measured in the field, and high-resolution airborne hyperspectral imagery, to map forest floor conditions after the 2004 Taylor Complex in Alaska's boreal forest. We applied a linear spectral unmixing model with five endmembers representing green moss, non-photosynthetic moss, charred moss, ash and soil to reflectance data to produce fractional cover maps. Our study sites spanned low to moderately high burn severity, and both black and white spruce forest types; high cover of green or non-photosynthetic moss in the remotely sensed imagery indicated low consumption, whereas high cover of charred moss, ash or soil indicated higher consumption. Strong relationships $\left(R^{2}=0.5\right.$ to 0.6$)$ between green moss estimated from the imagery and both post-fire depth and percentage consumption suggest that potential burn severity may be predicted by a map of green (live) moss. Given that the depth of the post-fire forest floor is ecologically significant, the method of mapping the condition of the organic forest floor with hyperspectral imagery presented here may be a useful tool to assess the effect of future fires in the boreal region.
\end{abstract}

Additional keywords: burn severity, carbon, duff, hyperspectral remote sensing, moss.

\section{Introduction}

Alaska boreal forest fires and fuels

Large, high severity wildfires have significantly altered the landscape in Alaska's boreal forest in recent years. In 2004, $2.7 \times 10^{6}$ ha burned, and in $2005,1.9 \times 10^{6}$ ha burned; the combined area burned during these 2 years accounts for nearly $10 \%$ of Alaska's boreal forest. Global climate change models predict warmer, longer and drier summers (Soja et al. 2007) leading to greater fire occurrence and severity (Flannigan et al. 2000, 2005; Gillett et al. 2004; Kasischke and Turetsky 2006) and a significant change in carbon storage and emissions (Kasischke et al. 1995a; Tan et al. 2007). Historically, wildland fires in the boreal forest tended to burn infrequently, as conditions were commonly too wet to burn. Typically, these fires burned slowly, over long periods of time, and created a large patchy mosaic of fire effects that were generally stand-replacing in black spruce (Picea mariana) forests (Foote 1983; Murphy et al. 2000). Recent large, severe fires have burned extensive areas and, in some cases, consumed future seed sources and exposed permafrost (Johnstone and Kasischke 2005; Johnstone and Chapin 2006). Extreme fire years have drawn attention to the role climate change may play in increasing the size, frequency and severity of future wildfires (Flannigan et al. 2000).

Wildfire is a major disturbance in interior Alaska, and ecological processes such as post-fire succession, carbon cycling and permafrost degradation can be dramatically changed directly and indirectly by fire (Johnstone and Chapin 2006; Kane et al. 2007; Johnstone et al. 2008; O'Donnell et al. 2009). 
(a)

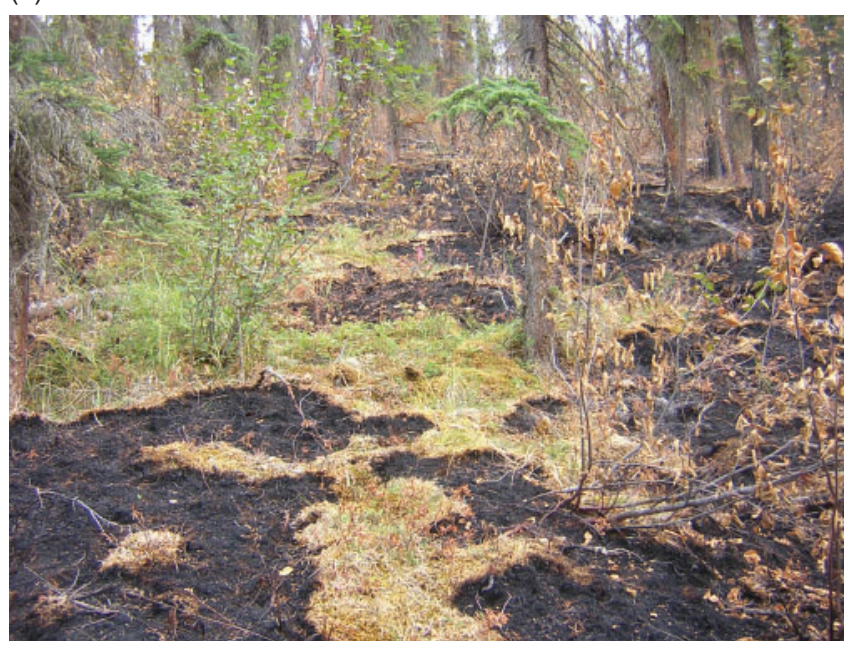

(b)

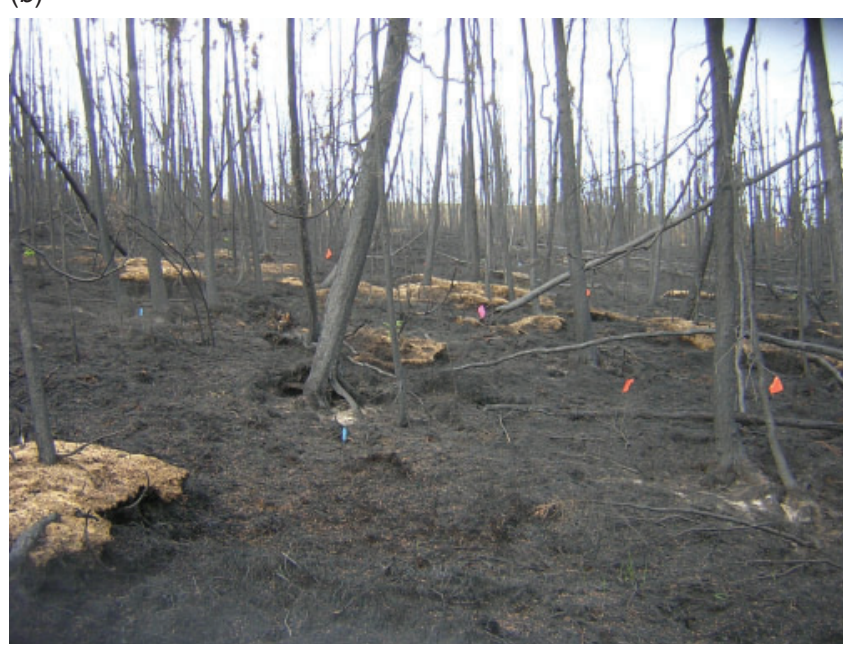

Fig. 1. Photos illustrating the mosaic of fire patterns in the boreal forest. Photo $(a)$ is low burn-severity site Wall Street Fire 2; and (b) is moderate burnseverity site Porcupine 7. In (a), islands of green are surrounded by a surface burn; in $(b)$, much of the forest floor is removed and soil and ash are visible at tree bases, interspersed with islands of lightly burned or unburned moss and duff.

The boreal forest biome contains a significant percentage $(\sim 12 \%)$ of the world's terrestrial carbon stored in the highly organic soil layers (Kasischke et al. 1995a; Harden et al. 2000; French et al. 2008; de Groot et al. 2009). Carbon emissions from organic material combustion have the greatest short-term direct effect on the carbon balance (French et al. 1996). Sandberg et al. (2002) reported that on average, fires in Alaska contribute $\sim 41 \%$ of the USA carbon emissions from wildland fires, and in years with large fires (e.g. 1990), $89 \%$ of USA emissions were from Alaskan fires. However, indirect effects of fire, such as changes in vegetation succession or thermal and hydrologic conditions of the soil surface may influence carbon storage for decades (O'Neill et al. 2003; Soja et al. 2007). The reduction of canopy shade and the loss of insulating organic layers may result in increased soil temperatures for months or years following a fire (Dyrness 1982; Dyrness and Norum 1983; Swanson 1996; O'Neill et al. 2002; Kasischke and Johnstone 2005). Extensive thawing of permafrost has caused increased erosion, landslides and ground subsidence and is projected to accelerate under future warming, resulting in discontinuous thawing, particularly of the top $10 \mathrm{~m}$ by 2100 (Schuur et al. 2008). Thus, the spatial and temporal variability of fires in boreal forests is significant on both regional and global scales (French et al. 1996; Duffy et al. 2007; Tan et al. 2007).

Heterogeneity in the boreal forest, not unlike other forests (see Hudak et al. 2007; Lentile et al. 2007a; Gould et al. 2008), is strongly correlated with the high spatial variability of burn severity (Miyanishi and Johnson 2002; Epting et al. 2005; Kasischke and Johnstone 2005; Duffy et al. 2007). The boreal forest floor can be characterised by a three- or a four-layer model of moss and duff in varying states of decomposition and compaction (Dyrness and Norum 1983; Kasischke et al. 1995a). The upper layer is composed of loosely compacted living moss and lichen. The moisture content of this layer can change rapidly with the ambient conditions, much like a dead fine fuel (Dyrness and Norum 1983; Kasischke et al. 1995a). The lower layers of decomposed moss, or duff, are increasingly compact, cooler and wetter - both upper and lower layers of moss provide insulation to the frozen soils below (permafrost) (Swanson 1996). The moss and duff layer is generally consumed by smouldering combustion (Miyanishi and Johnson 2002; Shetler et al. 2008), whereas canopy fuels are consumed under more moderate or severe burning conditions. When fire smoulders and creeps through the moss and duff layers, the degree of consumption is highly dependent on the pre-fire depth, moisture level and forest floor fuel moisture-holding capacity, which is dependent on bulk density and moss species (Dyrness 1982; Dyrness and Norum 1983; Miyanishi and Johnson 2002; Kasischke and Johnstone 2005; Greene et al. 2007; Shetler et al. 2008). Following high severity fires, the post-fire landscape is a complex, fine-scale mosaic of large burned patches where much of the forest floor is removed, interspersed with islands of lightly burned or unburned moss and duff (Dyrness and Norum 1983; Lentile et al. 2007a; Shetler et al. 2008) (Fig. 1).

\section{Satellite multispectral remote sensing of burn severity in Alaska}

The large geographic extent and the high spatial variability of wildfires in Alaska make these fires well suited for remotely sensed studies (French et al. 1996; Michalek et al. 2000; Kushida et al. 2007). Duffy et al. (2007) used Landsat satellite imagery to examine fire-vegetation interactions in Alaska and found that burn severity is affected by the topography of the landscape through interactions between fire and vegetation types, and burn severity generally increases with the size of the wildfire. Several recent articles found that Landsat-derived indices, specifically the Normalised Burn Ratio (NBR), differenced NBR (dNBR) and the field component, the Composite Burn Index (CBI) (Key and Benson 2005), were not ideally suited for mapping burn severity in Alaska's boreal forest (Epting et al. 2005; French et al. 2008). There is typically a greater proportion of high burn severity in a boreal forest fire and the $\mathrm{dNBR}-\mathrm{CBI}$ approach is not considered as accurate when the 
full range of severities is not present (French et al. 2008). The dNBR also has limited ability to discern fine-scale differences between moderate and high severity fires that can have significant ecological implications (Murphy et al. 2008). Subtle differences in depth of organic material remaining on moderate and high burn-severity sites are highly significant for tree seedling establishment and survival (Johnstone and Chapin 2006; Greene et al. 2007). Hoy et al. (2008) attempted to use dNBR (and other Landsat-derived indices and ratios) with CBI to estimate canopy and surface fuel consumption and found very low correlations between the remotely sensed and ground data.

One of the most ecologically significant reasons for mapping burn severity in Alaska is the high carbon content of the forest floor and soils and the significant emission of carbon into the atmosphere due to burning (de Groot et al. 2009). French et al. (1996) used various remotely sensed satellite images (AVHRR, Advanced Very High Resolution Radiometer; SPOT, Satellite Pour l'Observation de la Terre; and ERS-1 SAR, European Remote Sensing satellite Synthetic Aperture Radar) to map burn-area extent of a 1990 wildfire near Tok, Alaska. These data were combined with forest-floor biomass measurements to calculate carbon flux, which was estimated to be $33.2 \mathrm{t} \mathrm{ha}^{-1}$. Results in Kasischke et al. (1995b) concurred, reporting $28.8 \mathrm{t} \mathrm{ha}^{-1}$ high severity fires. Michalek et al. (2000) used Landsat data to estimate carbon emissions from black spruce stands (nearly $40 \mathrm{tha}^{-1}$ ) and concluded that the finer scale of Landsat compared with AVHRR imagery allowed for more spatially accurate estimates, which were also significantly higher than most previously reported values. Much lower estimates of carbon release after fire in the boreal region have been made in the range of 10 to $12 \mathrm{tha}^{-1}$ by Conard et al. (2002), Stocks (1991) and Cahoon et al. (1994). The fire type (canopy, surface or ground), type of vegetation burning and time of year all influence the degree of combustion and subsequent carbon release. These studies all indicate the need for further research to more accurately map high severity fires in the boreal region.

\section{Airborne hyperspectral remote sensing of burn severity in Alaska}

The utility of high-resolution hyperspectral imagery for mapping burn severity has not been evaluated in Alaskan boreal forest, but has been successfully used in temperate ecosystems to map burn severity (van Wagtendonk et al. 2004; Kokaly et al. 2007; Lewis et al. 2007; Robichaud et al. 2007). Airborne hyperspectral imagery facilitates mapping of discrete post-fire ground-cover components (green and scorched vegetation, ash and soil) (Kokaly et al. 2007; Lewis et al. 2007; Robichaud et al. 2007) at a finer scale than is possible using satellite-based data. The pixel size of an airborne hyperspectral image is as small as $1-5 \mathrm{~m}^{2}$ and acquisitions can cover many square kilometres. Airborne hyperspectral sensors record data in narrow bands of reflectance spectra arranged contiguously from the visible through the short-wave infrared (SWIR) range of the electromagnetic (EM) spectrum. The spectral bandwidth and sampling interval typically range from 10 to $20 \mathrm{~nm}$, resulting in more than 100 spectral bands. The spectral data volume of a hyperspectral image makes the application of high-level image processing techniques, such as spectral mixture analysis (SMA) more tractable.

For modelling purposes, a single image pixel is assumed to be a mixture of the individual reflectance spectra (endmembers) of the reflective surface materials (Adams et al. 1986; Roberts et al. 1993). In reality, a significant percentage of the reflectance from a pixel often comes from adjacent pixels or may be altered by instrument or atmospheric effects (Cracknell 1998; Townshend et al. 2000; Huang et al. 2002). The assumption of linear mixing has been shown to be appropriate and reasonably accurate when considering fire-affected surfaces (Rogan and Franklin 2001; Smith et al. 2005, 2007; Lewis et al. 2007; Robichaud et al. 2007). Once endmember spectra are identified, spectral unmixing algorithms can be used to estimate the fractional component spectra of individual pixels and, in turn, the physical fractional component of the materials within the pixels (Adams et al. 1986; Roberts et al. 1993; Theseira et al. 2003). To satisfy the need for accurate maps of post-fire ground cover in the boreal region, hyperspectral imagery may be used to derive fine-scale maps of remaining charred and uncharred forest-floor organic material as well as exposed mineral soil. We hypothesise that a high spectral fraction of remaining uncharred surface organics will indicate low consumption, whereas spectral fractions of exposed mineral soil or ash cover will indicate complete consumption of the forest-floor organic layer.

To investigate the utility of hyperspectral imagery for estimating post-wildfire forest-floor ground cover and consumption, we collected airborne hyperspectral imagery across 60550 ha of the 2004 Taylor Complex wildfire in Alaska. The specific objectives of this study were: (1) to compare the post-fire forest floor condition (remaining ground cover and percentage char) with forest floor consumption measurements (pre- and post-fire depth measurements); (2) to use airborne hyperspectral imagery to estimate the remaining ground cover (i.e. percentage green, brown and charred forest floor vegetation, ash and soil); (3) to validate the remotely sensed ground cover estimates with post-fire field data; and (4) to explore the utility of remotely sensed ground cover estimates to predict the depth and percentage consumption of the post-fire forest floor.

\section{Methods}

\section{Study area description}

Field sites were located on the Porcupine, Chicken and Wall Street Fires that burned in Alaska's interior boreal forest (Fig. 2). The Porcupine Fire began on 21 June 2004 and burned 115170 ha. The Chicken and Wall Street Fires began on 15 June 2004 and burned together with a combined area of 220150 ha. These wildfires eventually merged with other large wildfires to form the Taylor Complex (528218 ha; $63^{\circ} 43^{\prime} 28^{\prime \prime} \mathrm{N}$, $142^{\circ} 50^{\prime} 36^{\prime \prime} \mathrm{W}$, centroid; elevation 424 to $\left.1529 \mathrm{~m}\right)$. Because these wildfires burned simultaneously and merged within the same boreal forest ecosystem, we have treated all of our data for analysis purposes as samples from a single wildfire event, the Taylor Complex. The fires burned in forests of Picea mariana (black spruce) or P. glauca (white spruce) mixed with Populus tremuloides (quaking aspen), Betula neoalaskana (Alaska paper birch), Salix (willow) spp. and Alnus (alder) spp. All sites had 


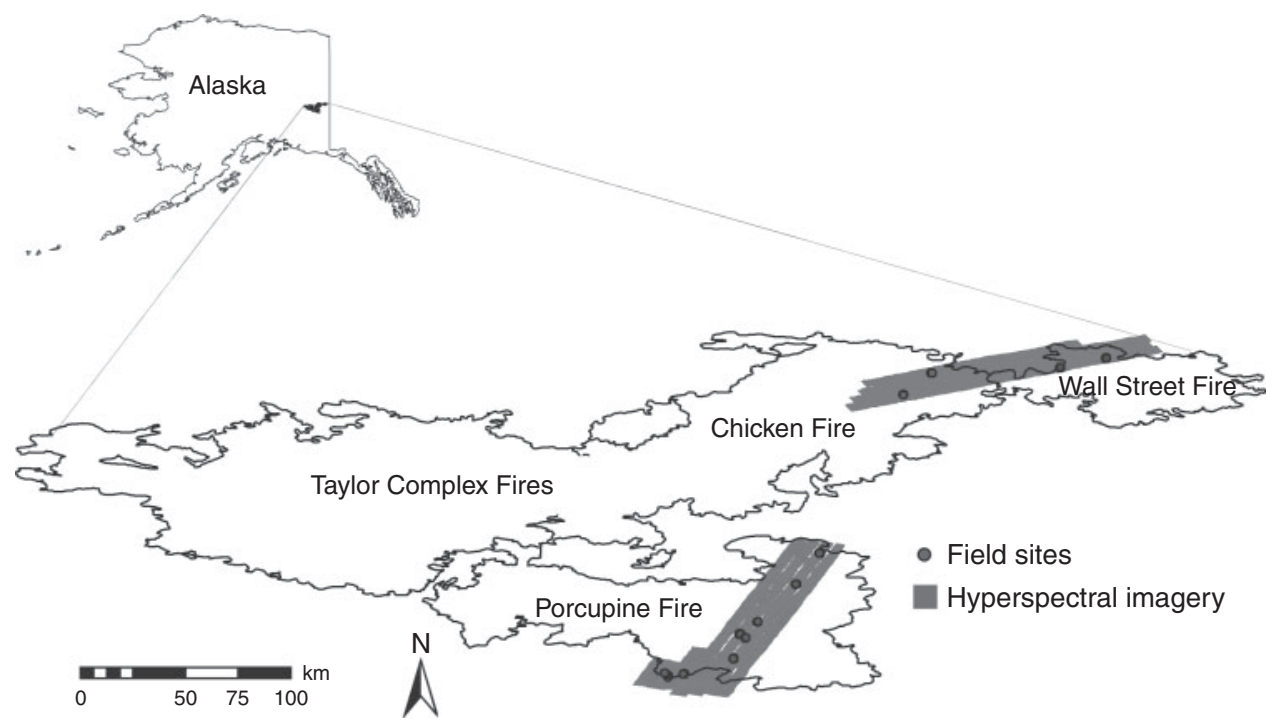

Fig. 2. Inset map of Alaska showing location and extent of the Taylor Complex. The locations of the field sites and image collection areas are shown in the larger image.

deep mats of Hylocomium splendens (feather moss) and other mosses (Lentile et al. 2007a) covering the forest floor.

For analysis, study sites were divided by dominant canopy vegetation, either black spruce or white spruce-hardwood mix because of the distinct differences in the composition of the surface organic layers (O’Neill et al. 2002; Harden et al. 2006). Black spruce sites tend to have deeper, wetter and colder organic layers that insulate and protect the underlying permafrost (Swanson 1996; Harden et al. 2006) and the highest fraction of carbon is generally in these organic layers (O'Neill et al. 2002; Kane et al. 2005). White spruce and hardwood sites have shallower aboveground organic layers that are often dryer because of the warmer, well-drained soils below (Swanson 1996). Thus, the organic layers rapidly transfer heat and moisture and are likely to be more combustible (Dyrness and Norum 1983; O'Neill et al. 2002). The soils in white spruce and hardwood sites contain a greater percentage of carbon than the aboveground organic layers and are often exposed after fire owing to the combustibility of the organic layers.

\section{Field data}

\section{Sampling overview}

Three collaborating but independent rapid-response research teams (Lentile et al. 2007b) collected pre- and post-fire data on the Taylor Complex wildfires in July 2004. These teams were led by coauthors Ottmar, Hood and Hudak (Table 1). Importantly, in the present paper, the term 'site' is used to describe widely separated $(>300 \mathrm{~m}$ ) sample locations chosen by the three different rapid-response teams across the landscape, whereas the terms 'plot' and 'subplot' describe spatially nested sample units within a site. All sites were randomly located within areas that were considered safe to access before they burned. The Ottmar team collected a suite of pre- and post-fire fuels, ground cover and consumption data at 13 sites on the Taylor Complex, nine of which burned. These sites were 'large' in that they consisted of nine (by design) plots randomly selected and systematically arranged, separated by a $20.12-\mathrm{m}$ (66-foot) chain length. The Hood team characterised pre-fire fuels and vegetation at comparatively 'small' sites, in that they consisted of a single plot. The Hudak team collected the post-fire forest floor depth and consumption measures on six of the nine small sites established by the Hood team that burned. The Hudak team mainly collected a suite of post-fire effects measures at 16 sites, 10 large and 6 small, described as follows: nine large sites overlapped with the Ottmar team's nine large sites that burned; six small sites colocated with the Hood team's six sites that burned (the two small sites that burned at low severity were expanded into large sites to include more low severity sample plots); a final large site colocated with neither the Hood nor the Ottmar team's sites (i.e. no pre-fire data) that was added to incorporate a low severity white spruce site (Table 1).

\section{Forest floor consumption data}

By design, the Ottmar team measured pre- and post-fire forest floor depths at nine plots per site; depth measurements were made at 16 predetermined locations per 2-m-radius circular plot. A duff pin was inserted until the top of the duff pin was flush with the top surface of the duff or an obstruction was met. If the latter was the case, the top of the duff pin was clipped to be level with the surface of the duff. At two locations in each plot, a duff sample ( $\sim 150 \mathrm{~mm}$ square by $250 \mathrm{~mm}$ deep) was removed and the depth of each duff layer was measured (i.e. live moss layer, dead moss layer, upper duff and lower duff). These plug samples were also used to determine fuel moisture by weight (by drying at $105^{\circ} \mathrm{C}$ and reweighing) for each stratum. Following the fire, the height of the pin above the top-most remaining duff surface was measured with a ruler $( \pm 1 \mathrm{~mm})$ to gauge forest floor consumption. The depth of the remaining forest floor layers was also measured down to permafrost or mineral soil (whichever was encountered first) and compared with pre-fire forest 
Table 1. Sites sampled on the Taylor Complex Fires $(n=16)$

Sites are sorted by major vegetation type: black spruce (BS) and white spruce (WS) or white spruce-hardwood mix (WS-H) and then by least to greatest percentage forest floor consumption. The plot numbers indicate the number of plots with data at each site; the numbers in parenthesis under the Ottmar team indicate the number of plots that were geolocated and used in the spatial autoregressive models. The site names were assigned by the Hudak team and do not include Hood or Ottmar pre-fire team sites that did not burn

\begin{tabular}{|c|c|c|c|c|c|c|c|c|c|}
\hline \multirow[b]{2}{*}{ Site name } & \multirow[b]{2}{*}{ Vegetation } & \multicolumn{4}{|c|}{$\begin{array}{l}\text { Site characteristics } \\
\text { Forest floor depth }\end{array}$} & \multirow{2}{*}{$\begin{array}{c}\text { Ground cover } \\
\text { Hudak (post-fire) }\end{array}$} & \multicolumn{3}{|c|}{$\begin{array}{l}\text { Plot numbers } \\
\text { Consumption }\end{array}$} \\
\hline & & Pre-fire $(\mathrm{mm})$ & Post-fire (mm) & $\begin{array}{l}\text { Consun } \\
(\mathrm{mm})\end{array}$ & $\begin{array}{l}\text { tion } \\
(\%)\end{array}$ & & Hood (pre-fire) & $\begin{array}{l}\text { Ottmar (pre- } \\
\text { and post-fire) }\end{array}$ & Hudak (post-fire) \\
\hline Wall Street 1 & BS & 208 & 150 & 58 & 28 & 9 & & $9(2)$ & \\
\hline Chicken 2 & BS & 214 & 136 & 78 & 36 & 9 & & $9(5)$ & \\
\hline Porcupine 8 & BS & 185 & 102 & 83 & 45 & 9 & & $9(3)$ & \\
\hline Porcupine 5 & BS & 197 & 102 & 95 & 48 & 9 & 1 & & 1 \\
\hline Porcupine 7 & BS & 204 & 97 & 107 & 53 & 9 & & $9(4)$ & \\
\hline Chicken 1 & BS & 188 & 85 & 103 & 55 & 9 & & $18(12)$ & \\
\hline Porcupine 9 & BS & 225 & 78 & 147 & 65 & 9 & & $8(2)$ & \\
\hline Porcupine 10 & BS & 198 & 65 & 133 & 67 & 9 & & $8(3)$ & \\
\hline Porcupine 1 & BS & 155 & 43 & 112 & 72 & 9 & & $18(11)$ & \\
\hline Porcupine 3 & WS-H & 127 & 51 & 76 & 60 & 1 & 1 & & 1 \\
\hline Porcupine 12 & WS & 108 & 31 & 77 & 71 & 1 & 1 & & 1 \\
\hline Porcupine 11 & WS & 83 & 15 & 68 & 82 & 1 & 1 & & 1 \\
\hline Porcupine 4 & WS & 108 & 12 & 96 & 89 & 1 & 1 & & 1 \\
\hline Porcupine 6 & WS-H & 216 & 23 & 193 & 89 & 9 & 1 & & 1 \\
\hline Porcupine 2 & WS & 105 & 7 & 98 & 93 & 9 & & $16(9)$ & \\
\hline Wall Street 2 & WS & - & - & - & - & 9 & & & \\
\hline
\end{tabular}

floor data to determine the fraction of each of the four layers consumed.

The Hood team measured pre-fire forest floor depths at a single $10 \times 10$-m-square plot at each site. Total depth to permafrost or mineral soil and the proportion of the total depth composed of litter and moss were measured with a ruler $( \pm 1 \mathrm{~mm})$ at four locations in each plot, and duff pins were placed at the four plot corners. The Hudak team measured exposed duff pin heights following the fire to determine consumption.

\section{Ground cover data}

The Hudak team collected post-fire soil and vegetation data between 23 and 31 July 2004 at 16 sites (Table 1). Site selection by the Hudak team was guided by two considerations. The first consideration was to attempt to cover the full range of burn severity observed across the post-fire landscape. A Burned Area Reflectance Classification (BARC) map (RSAC 2005) was used only for guidance to locate sites that were predominantly green (low burn severity), brown (moderate) or black (high) in terms of vegetation effects, as the BARC has been shown to be less than ideal for mapping fires in the boreal region. The second consideration was to match pre- and post-fire data by capitalising on the opportunity to remeasure pre-fire sites established by the Ottmar and Hood teams. On the Porcupine Fire, two sites were originally classified as low burn severity, four as moderate and six as high. On the Chicken and Wall Street Fires, two sites were originally classified as low burn severity, one as moderate and one as high.

The spatial extent and sampling intensity of the Hudak team measuring post-fire effects matched the spatial extent and sampling intensity of the Ottmar or Hood teams that had established the sites beforehand. Sites were centred in a random location $80-140 \mathrm{~m}$ from the nearest access road, within a consistent vegetation type and burn severity condition. At 10 sites including the nine Ottmar team sites, the Hudak team installed nine $9-\mathrm{m}^{2}$ plots spaced $20-40 \mathrm{~m}$ apart, with each plot composed of fifteen $1-\mathrm{m}^{2}$ subplots, for a total of 135 subplots per site, following a systematic, spatially nested design detailed in Hudak et al. (2007). At the six sites overlaying a Hood team site, a single plot composed of 15 subplots (as just described) was installed. The Hudak team geolocated the centre subplot of each their plots using a Trimble Geo-XT (Trimble Navigation Limited, Westminster, CO) GPS with differential correction capability (submetre accuracy), logging a minimum of 150 positions per plot with a threshold PDOP (position dilution of precision) of 6 . Locations of the other subplots and plots were calculated based on their systematic distance and angular offsets from plot centre. The accuracy of the georeferenced imagery was checked by logging GPS coordinates at highly visible road intersections; the differentially corrected, averaged positions overlaid as close to the centre of these intersections as could be visibly discerned (within 1-2 pixels). Thus the plot locations were considered accurately located within the imagery. The Hudak team's heavy emphasis on subplot-level geolocation facilitated aggregation of the subplot-level ground-cover measures to the plot level for the purpose of hyperspectral image validation.

At the subplot scale $\left(1 \mathrm{~m}^{2}\right)$, the fractional cover of green vegetation, litter, coarse woody debris and other non-photosynthetic vegetation (NPV), ash, exposed mineral soil and rock were visually estimated. The percentage char of each non-green 


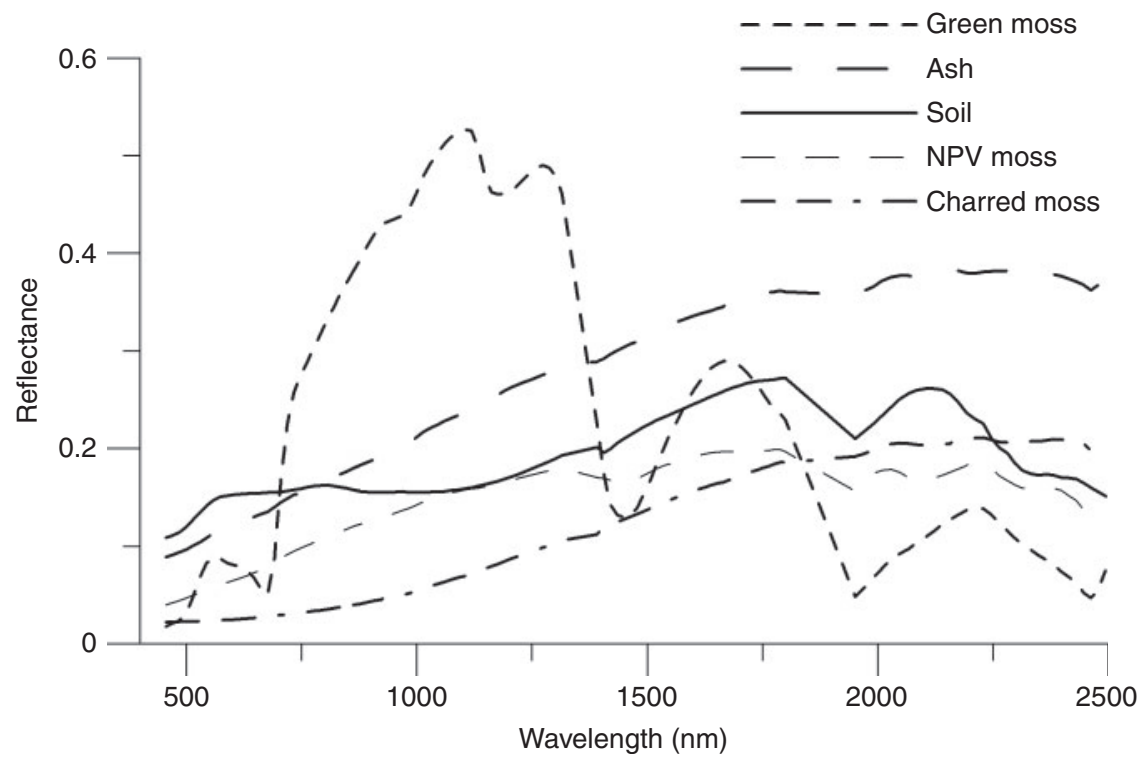

Fig. 3. Spectral reflectance of the endmembers used in the spectral mixture analysis (NPV, non-photosynthetic vegetation).

ground-cover component was also recorded. Minor groundcover fractions were estimated first, and a value of $1 \%$ was recorded if there was a trace of the component within the subplot. The more abundant fractional ground-cover components were then estimated with the largest cover component (often charred or uncharred NPV) estimated last. The ocular fractional cover estimates were constrained to sum to unity $(100 \%)$.

\section{Field spectra}

Multiple spectra of green, NPV, charred NPV, ash and soil materials (Fig. 3) were collected during the field campaign in 2004, and again in July 2005 using an ASD Pro-FR field spectroradiometer (Analytical Spectral Devices, Boulder, CO). Spectra were collected with the bare-tip foreoptic (field of view, FOV, $22^{\circ}$ ) pointed at the target material from a height of $\sim 1 \mathrm{~m}$. The ASD Pro-FR sampling interval is $1.4 \mathrm{~nm}$ over the 350 - to $1050-\mathrm{nm}$ wavelength range and $2 \mathrm{~nm}$ over the 1000 - to $2500-\mathrm{nm}$ range, spanning nearly the same portion of the EM spectrum as the HyMap sensor used for airborne imaging (HyVista Corporation, Sydney, Australia). These measurements are interpolated at every 1-nm wavelength and reported in 2151 contiguous channels. The field spectrometer was calibrated against a Spectralon (Labsphere, North Sutton, NH) 100\% reflective panel immediately before and at frequent intervals during field spectra collection to account for changing light and atmospheric conditions. Absolute reflectance was calculated at the time of data collection for all spectra by dividing field reflectance by the bright target reflectance.

Bright and dark target reference calibration spectra were also collected for use in an Empirical Line Calibration (ELC), which forces spectral data from the image to match selected field reflectance spectra (Richards and Jia 1999). The bright target was a $250-\mathrm{m}^{2}$ sheet of highly reflective white Tyvek (DuPont Corporation, Wilmington, DW) material and the dark target was a similarly sized sheet of non-reflective (matte) black landscape fabric. Calibration reflectance spectra of these two materials were collected on the same day as the airborne image acquisition, which was cloud-free. Two paired spectra (bright and darkimage and field) were used in the ELC. A linear regression was calculated by fitting the regression line through both pairs of spectra for each band to equate the digital number and reflectance. The ELC minimises atmospheric and illumination effects by standardising them across all bands in the image.

\section{Image pre-processing}

Airborne HyMap hyperspectral data were collected on 3 August 2004. The sensor was mounted to a fixed-wing aircraft flown at an average altitude of $2300 \mathrm{~m}$, and data were collected between 1930 and 2230 hours UTC (Universal Coordinated Time) (solar noon 2135 hours UTC). The HyMap sensor collects data in 128 spectral channels across the range of 450 to $2500 \mathrm{~nm}$. The instantaneous field of view (IFOV) is $2.5 \mathrm{~m}$ along-track and $2.0 \mathrm{~m}$ across-track and the FOV is $61^{\circ}$ (512 pixels). The mean spatial resolution of the images was $3 \mathrm{~m}$. Image geolocation was achieved with an onboard GPS (3-10-m accuracy) and integrated inertial monitoring unit. Imagery was collected for 26000 and 34550 ha over the field sites on the Chicken-Wall Street and Porcupine Fires respectively. All field sites on both fires were within the area of image collection (Fig. 2).

Raw radiance data were corrected to apparent surface reflectance using the HyCorr software package (HyVista Corporation, Sydney, Australia). This is essentially a two-step process, first correcting for atmospheric absorption and scattering with ATREM (Atmospheric Removal) (Gao et al. 1993), followed by EFFORT (Empirical Flat Field Optimal Reflectance Transformation) polishing to remove systematic ATREM errors (Boardman 1998). These corrected reflectance data were used in the ELC, as explained above. Bands 1, 31 and 126 (450, 863 and $2493 \mathrm{~nm}$ ) were removed owing to noise and bands 63-65 (1390-1420 nm) and 94-97 (1790-1989 nm) were removed owing to atmospheric water absorption before further image processing. 

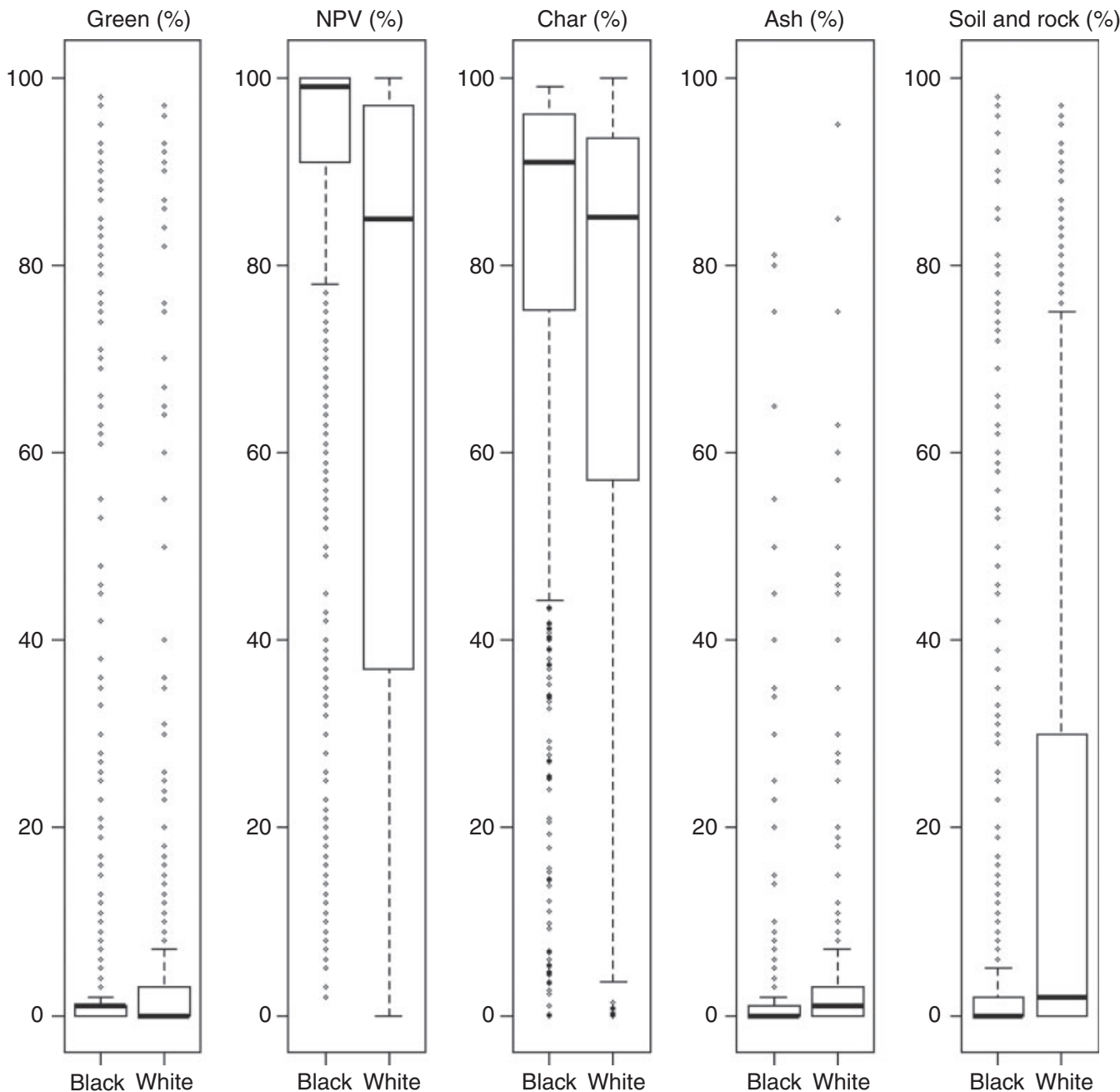

Fig. 4. Box and whisker plots illustrating the variability in subplot-level ground cover measurements at 16 sites characterised by the Hudak team. Measures are separated into 'black' $(n=1215)$ and 'white' $(n=465)$ spruce forest types. The dark line shows the median, the box indicates the interquartile range and the whiskers extend to the most extreme data point that is no more than the range times the interquartile range from the box (NPV, non-photosynthetic vegetation).

\section{Image analysis}

A linear spectral unmixing algorithm was applied to the fully preprocessed hyperspectral data to determine pixel fractions of green, NPV and charred vegetation, ash and soil cover:

$$
\begin{aligned}
\rho_{\text {pixel }}= & \sum\left\{\rho_{e} C_{e}\right\}+\varepsilon=\left\{\rho_{\text {green }} C_{\text {green }}+\rho_{\mathrm{NPV}} C_{\mathrm{NPV}}\right. \\
& \left.+\rho_{\text {char }} C_{\text {char }}+\rho_{\text {ash }} C_{\text {ash }}+\rho_{\text {soil }} C_{\text {soil }}\right\}+\varepsilon \sum C_{e}=1.0
\end{aligned}
$$

where $\rho$ and $C$ are the reflectance and cover fraction of each endmember respectively and $\varepsilon$ is an error term. The individual cover fractions are forced to sum to unity. The spectra used in the SMA are shown in Fig. 3. The products of SMA are fractional cover images for each of the input materials. In addition to the fractional cover images, a root mean square error (RMSE) image is also produced, which indicates the residual error for partitioning the mixed image pixel spectrum into the component endmember spectra. The average RMSE was 0.05 or less and randomly distributed across both fire images, indicating that these endmembers matched the ground cover types in the image. The fractional cover estimates were extracted from the unmixed hyperspectral images at all subplot locations. Fractional cover estimates ideally are scaled from 0 to 1 , but in practice the SMA output images deviate to a slightly broader range. Therefore, negative cover fractions were truncated to 0 , and then the values in each cover fraction were rescaled slightly to range from 0 (minimum value) to 1 (maximum value) to reflect the real range of variability on the ground. Zero indicates that none of the target material is present in the pixel, whereas 1 indicates complete cover. Finally, the fractional cover values were rescaled to sum to unity at each subplot location, which was the same constraint applied to the field fractional cover estimation on the ground.

\section{Statistical analysis}

The three rapid-response teams contributing to this analysis used different plot sampling designs per site. Therefore, any comparisons of data collected by different teams required that 

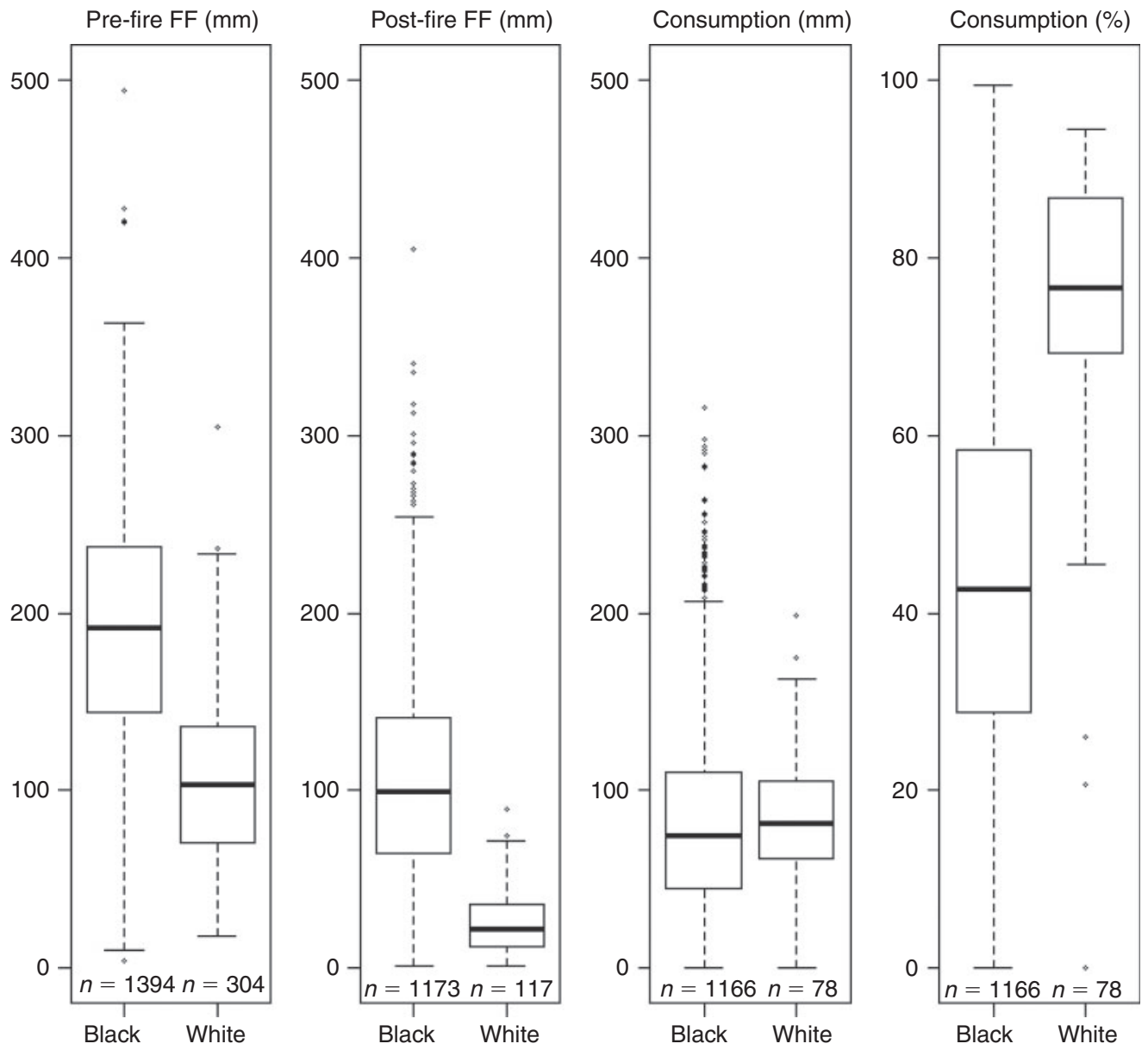

Fig. 5. Box and whisker plots illustrating the variability in forest floor (FF) depth or consumption pin measurements at 15 sites characterised by the three rapid-response research teams. Measures are separated into 'black' and 'white' spruce forest types, with the number of measures reported at the bottom. The dark line shows the median, the box indicates the interquartile range and the whiskers extend to the most extreme data point that is no more than the range times the interquartile range from the box.

the data be aggregated to the site level. Site means of the fieldmeasured ground-cover data and the forest floor depth and consumption data were compared across the 15 sites where both sets of measurements were taken by the combined efforts of the three rapid-response teams. Box plot figures were created to illustrate the range and distributional shape of ground cover (Fig. 4), forest floor depth and consumption (Fig. 5) measurements on the field sites. Correlations were assessed for each ground-cover type compared with the forest floor depth and consumption measures (Table 2) with the non-parametric Spearman rank-sum correlation statistic. Statistics were calculated in both R (R Development Core Team 2004) and SAS (SAS Institute Inc. 2002). The same correlation statistics were used to compare field-measured fractional ground cover with remotely sensed spectral fractions (Table 3 ) to evaluate how well the image captured the conditions on the ground at 16 sites where these variables were measured by the Hudak team. Based on statistically significant relationships $(P<0.05)$ between the image and field data, the remotely sensed spectral fractions were also compared with the forest floor depth and consumption measurements at the 15 coincident sites where pre-fire measures were available. Multiple linear regression models were developed using the SMA fractional cover estimates as predictor variables at 51 geolocated field plots where pre- and post-fire forest floor depths were measured by the Ottmar team. The significant models for predicting post-fire forest floor depth and percentage forest floor consumption showed evidence of spatial dependence in the residuals, so they were improved into spatial simultaneous autoregressive models (Haining 1990; Cressie 1993). A spatial simultaneous autoregressive model consists of a non-spatial trend, a spatial signal and the residual error. Predicted values are the sum of the non-spatial trend and spatial signal components. Predictor variables for the trend component were selected using a stepwise procedure based on the Akaike Information Criterion (AIC) goodness-of-fit statistic (Table 4).

\section{Results}

\section{Observed ground cover and consumption data}

Measures of fine-scale ground cover in the $1-\mathrm{m}^{2}$ subplots were highly variable on both the black spruce and white spruce field sites (Fig. 4). On both the black and white spruce sites, NPV was 
Table 2. Spearman correlation coefficients $(\rho)$ between field-measured forest floor depth and consumption measures with ground cover measures Data were collected by three rapid response teams $(n=15$ sites $)$. Correlations with absolute values $>0.5$ are significant $(P<0.05)$ and are indicated in bold. NPV, non-photosynthetic vegetation

\begin{tabular}{lcrrrr}
\hline & & & \multicolumn{2}{c}{ Post-fire ground cover } \\
& Green $(\%)$ & NPV (\%) & Char (\%) & Ash (\%) \\
\hline Pre-fire forest floor depth (mm) & $\mathbf{0 . 7 7}$ & $\mathbf{0 . 6 2}$ & $\mathbf{- 0 . 6 8}$ & -0.33 \\
Post-fire forest floor depth (mm) & $\mathbf{0 . 6 2}$ & $\mathbf{0 . 7 6}$ & $\mathbf{- 0 . 5 3}$ & $-\mathbf{0 . 6 1}$ \\
Forest floor consumption depth (mm) & 0.21 & 0.16 & 0.20 & 0.21 \\
Forest floor consumption (\%) & $\mathbf{- 0 . 5 2}$ & $\mathbf{- 0 . 7 4}$ & 0.49 & $\mathbf{0 . 8 0}$ \\
\hline
\end{tabular}

Table 3. Spearman correlation coefficients $(\rho)$ between remotely sensed image data (spectral mixture analysis (SMA) fraction) and field ground cover data

Data were collected by the Hudak rapid response team $(n=16$ sites $)$. Spearman correlation coefficients with absolute values $>0.5$ are significant $(P<0.05)$ and are indicated in bold. NPV, non-photosynthetic vegetation

\begin{tabular}{|c|c|c|c|c|c|c|}
\hline \multirow[t]{2}{*}{ SMA fraction } & \multicolumn{6}{|c|}{ Post-fire ground cover } \\
\hline & Green $(\%)$ & Uncharred NPV (\%) & Charred NPV (\%) & Total char $(\%)$ & Ash (\%) & Soil and rock (\%) \\
\hline Green moss & 0.89 & 0.86 & -0.04 & -0.89 & -0.53 & -0.52 \\
\hline NPV moss & 0.02 & -0.03 & -0.31 & 0.01 & -0.03 & 0.07 \\
\hline Charred moss & 0.07 & -0.13 & 0.63 & 0.14 & -0.32 & -0.29 \\
\hline Ash & 0.05 & 0.19 & -0.36 & -0.24 & 0.28 & 0.27 \\
\hline Soil and rock & -0.28 & -0.19 & 0.20 & 0.23 & 0.18 & 0.15 \\
\hline
\end{tabular}

Table 4. Spatial autoregression models for predicting ( $a$ ) post-fire forest floor depth, and $(b)$ percentage forest floor consumption The spectral mixture analysis (SMA) image variables are the predictor variables at 51 field plots established by the Ottmar team; only the significant predictor variables are included, selected by a stepwise procedure based on the Akaike Information Criterion (AIC). Significance levels are as follows: $* * *, P<0.001$; **, $P<0.01{ }^{*}, P<0.05 ; \cdot, P>0.05$. NPV, non-photosynthetic vegetation

\begin{tabular}{|c|c|c|c|c|c|}
\hline Predictor variable & Coefficients & Standard error & $z$ value & $\operatorname{Pr}(>|z|)$ & Significance \\
\hline \multicolumn{6}{|c|}{ (a) Post-fire forest floor depth (mm) } \\
\hline (Intercept) & -61.2 & 41.2 & -1.5 & 0.14 & $\cdot$ \\
\hline Green moss & 291.5 & 74.5 & 3.9 & $9.2 \times 10^{-5}$ & $* * *$ \\
\hline NPV moss & 130.3 & 41.6 & 3.1 & 0.002 & $* *$ \\
\hline Charred moss & 87.6 & 59.9 & 1.5 & 0.14 & . \\
\hline \multicolumn{6}{|c|}{ (b) Percentage forest floor consumption (\%) } \\
\hline (Intercept) & 99.1 & 20.4 & 4.9 & $1.1 \times 10^{-6}$ & $* * *$ \\
\hline Green moss & -146.8 & 32.9 & -4.5 & $7.9 \times 10^{-6}$ & $* * *$ \\
\hline NPV moss & -76.6 & 18.4 & -4.2 & $3.1 \times 10^{-5}$ & $* * *$ \\
\hline Charred moss & -63.6 & 26.9 & -2.4 & 0.02 & $*$ \\
\hline
\end{tabular}

the dominant ground cover (mean 88 and $68 \%$ respectively of the ground area in subplots) (Fig. 4). Little green vegetation was measured on either the black or white spruce sites (mean 6 and $8 \%$ ). The white spruce sites had more inorganic ground cover (19\% soil and rock cover and 5\% ash cover) than the black spruce sites (5\% soil and rock cover and $2 \%$ ash cover). The mean percentage ground cover of char (the sum of all charred components within the plot) was similar on both the black and white spruce sites, 79 and $70 \%$ respectively.

The total depth of the pre-fire organic forest floor was much deeper on the black spruce sites (mean $193 \mathrm{~mm}$ ) than on the white spruce sites $(106 \mathrm{~mm})$, and the total organic forest floor depth remaining after the fire was greater on the black spruce sites $(110 \mathrm{~mm})$ than the white spruce sites $(27 \mathrm{~mm})$ (Fig. 5). The total depth of consumption on both the black spruce and white spruce sites was similar, 83 and $85 \mathrm{~mm}$ respectively. However, the total percentage consumption of the organic forest floor was much greater on the white spruce sites $(75 \%)$ as compared with the black spruce sites (43\%).

\section{Relationship between post-fire ground cover and} forest floor depth and consumption

Both pre- and post-fire forest floor depth were significantly correlated with nearly all of the post-fire ground cover variables, with the exception of the correlation between pre-fire forest floor depth and ash (Table 2). Plots with extensive remaining 


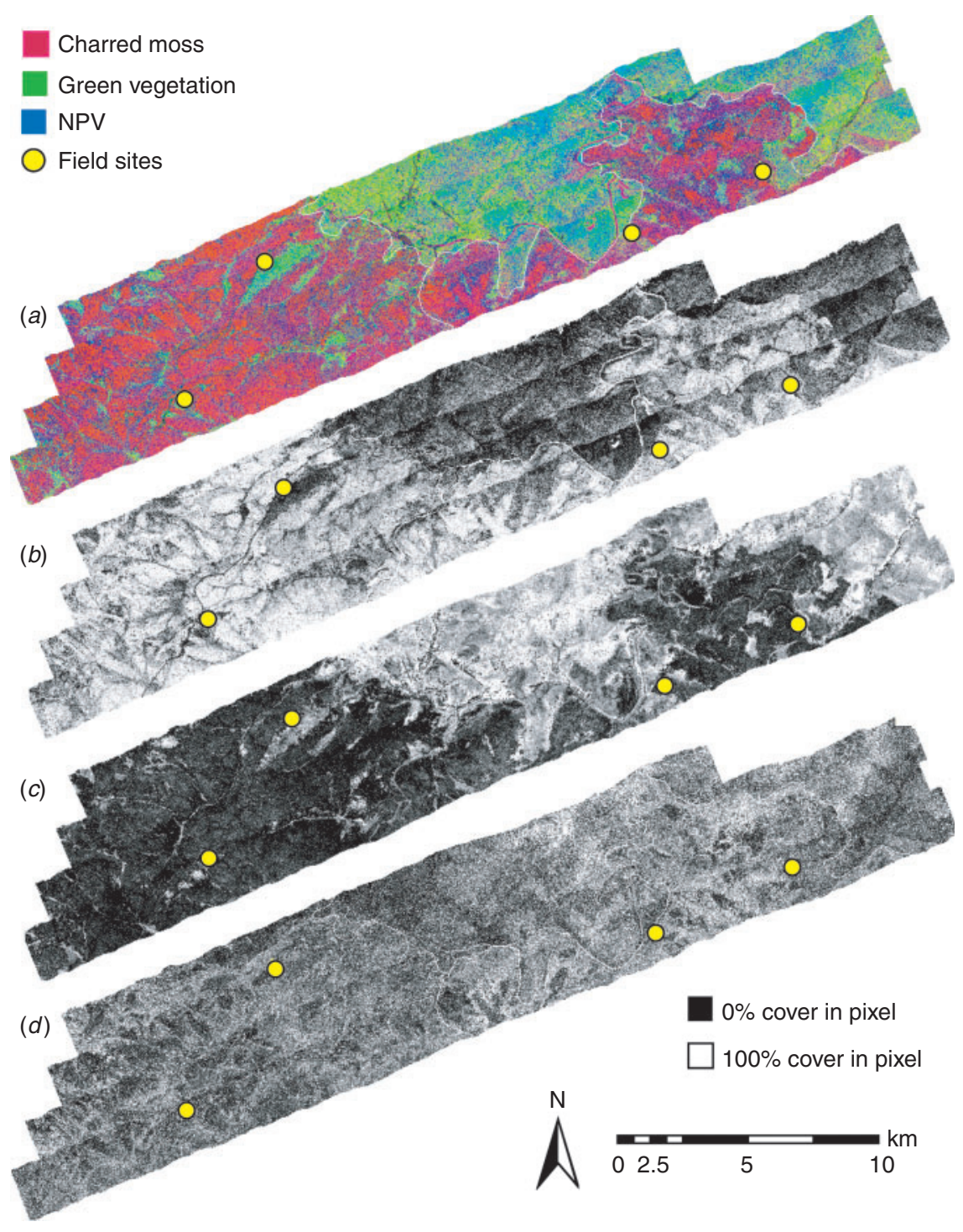

Fig. 6. Imagery collected from the Chicken and Wall Street Fires. The fire perimeter is a thin white line on $(a)$, which is a red-green-blue colour composite of the imagery. Red represents charred moss, green represents green vegetation and blue represents non-photosynthetic vegetation (NPV). Greyscale images show individual components: $(b)$ charred moss; $(c)$ green vegetation; and $(d)$ NPV.

green and NPV ground cover and limited soil exposure (i.e. deep forest floor layers) were indicative of low burn severity. Forest floor consumption depth was not significantly correlated with any of the post-fire ground cover variables, but percentage forest floor consumption was significantly correlated with green vegetation, NPV, ash and soil and rock cover fractions, and almost significantly correlated with char fraction $(P=0.066)$ (Table 2). The higher severity plots had the greatest percentage consumption and were characterised by little remaining moss and duff and more soil and ash cover.

\section{Relationship between spectral unmixing results and post-fire ground cover}

The outputs of the SMA were individual greyscale images of estimated fractional cover for each of the input endmember spectra from Fig. 3 (green and NPV moss, charred moss, ash and soil). These images can either be viewed separately to analyse patterns of a single ground-cover type, or they can be combined in a coloured image that better illustrates the components of mixed pixels. Fig. 6 shows a mosaic of the four strips of imagery that were collected over the Chicken-Wall Street Fire field sites. Fig. $6 a$ is a red-green-blue colour composite of charred moss, green vegetation and NPV. The perimeter of the fire is an overlaid thin white line and the field sites are overlaid as yellow circles. With this colour scheme, the mapped ground-cover pattern closely matches the fire perimeter (mapped independently from Landsat imagery following Hudak and Brockett 2004), with nearly all of the charred vegetation (red) south of the perimeter and most of the unburned vegetation (green) to the north. The widespread NPV, which is mostly brown moss, is visible in blue on both sides of the fire perimeter. 

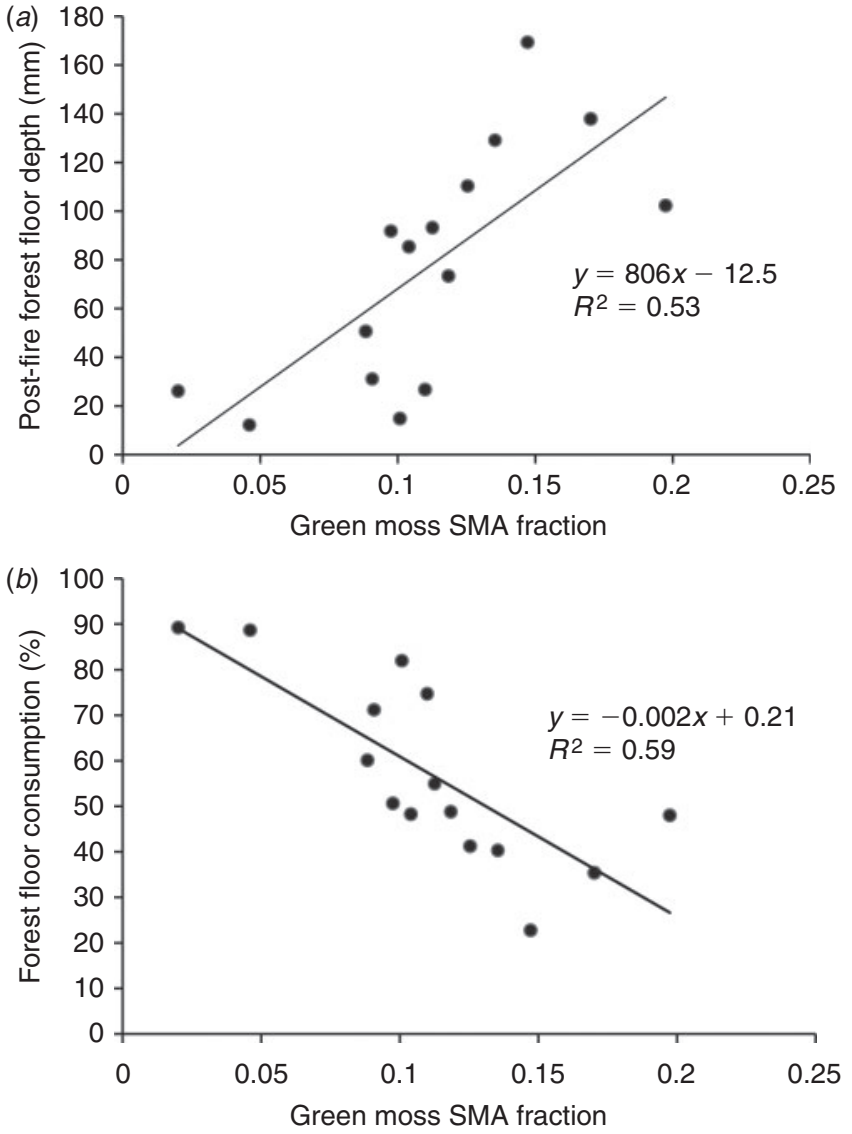

Fig. 7. Scatterplots of the green moss spectral mixture analysis (SMA) fraction $v$. (a) post-fire forest floor depth $(\mathrm{mm})$, and $(b)$ percentage forest floor consumption (\%) from the 15 sites where consumption measurements were taken. Linear regressions were calculated and coefficients of determination are reported.

The greyscale images (Fig. $6 b, c, d$ ) highlight the individual component materials. The patterns of the fire are fairly clear in Fig. $6 b$ (charred moss) and $6 c$ (green vegetation), with the bright pixels indicating a significant presence of the material in a pixel and the dark pixels having little or no presence. In Fig. $6 d$, NPV is a little more difficult to interpret because it is found ubiquitously throughout the area, but in smaller concentrations and at fine scales, i.e. there are fewer bright white pixels and more grey pixels. Uncharred tree and shrub bark also contribute to this fractional cover estimate.

To evaluate how well the spectral unmixing results represented the conditions on the ground, correlations were calculated between the image SMA and ground fractional cover data at the 16 field sites characterised by the Hudak team (Table 3). For this comparison, the uncharred and charred components of the predominant NPV cover fraction were separated because their spectral reflectance differs greatly. The green moss SMA fraction was significantly positively correlated with green $(\rho=0.89)$ and uncharred NPV $(0.86)$ ground cover and negatively correlated with total char $(-0.89)$, ash $(-0.53)$ and soil and rock $(-0.52)$ cover. The charred moss SMA fraction was significantly positively correlated with the charred NPV ground $\operatorname{cover}(\rho=0.63)$.

\section{Relationship between remotely sensed fractional cover and forest floor consumption}

Based on the many significant relationships found between postfire ground cover and pre- and post-fire forest floor depths and percentage consumption (Table 2), and some significant relationships between the SMA results and post-fire ground cover (Table 3), linear regressions were calculated between SMA fractional cover estimates and consumption data (Fig. 7). As before, the green moss SMA fraction proved the most useful image variable, producing strong correlations with post-fire forest floor depth $(\rho=0.83, P=0.0002)$ and percentage consumption $(\rho=-0.86, P<0.0001)$. Charred moss SMA fraction was the second most useful image variable, which was significantly correlated with post-fire forest floor depth $(\rho=0.53$, $P=0.045)$ and almost significantly correlated with percentage consumption $(\rho=-0.50, P=0.06)$.

Our results (Fig. 7) portended some ability to predict postfire forest floor depth and percentage forest floor consumption using SMA fractional cover estimates as predictor variables. Fortunately, the Ottmar team geolocated some of their field plots, allowing the forest floor and SMA variables to be related at 51 coincident plot locations for the purpose of developing predictive regression models (Table 4). As suggested by the correlations in Tables 3 and 4, only the SMA estimates of the three moss fractions (green, NPV and charred) proved significant predictors in the trend component of the spatial simultaneous autoregressive models (Table 4). Including a spatial component in the post-fire depth model $(\mathrm{AIC}=499.91, \log$ likelihood, $\log \mathrm{Lik}=-243.96$ ) was a significant improvement (likelihood ratio, L.Ratio $=18.7, P<0.0001$ ) over the nonspatial linear model $(\mathrm{AIC}=516.62, \log \mathrm{Lik}=-253.31)$ and reduced the RMSE from 36.2 to $29.1 \mathrm{~mm}$. Including a spatial component in the percentage consumption model (AIC $=$ 418.32, $\log$ Lik $=-203.16$ ) was also a significant improvement (L.Ratio $=4.8, P=0.0287$ ) over the non-spatial linear model $(\mathrm{AIC}=421.10, \log \mathrm{Lik}=-205.55)$ and reduced the RMSE from 14.2 to $13.4 \%$. Finally, both spatial simultaneous autoregressive models lacked significant spatial dependence in the residuals (post-fire depth, $P=0.6$; percentage consumption, $P=0.5$ ), unlike the residuals of the non-spatial linear models $(P<0.001$ in both cases).

The Ottmar team data used to develop the regression models in Table 4 were based on 606 consumption pin measures at 51 plots geolocated with GPS. There were another 632 consumption pin measures from 53 plots that were not geolocated, which served as independent validation data for these models. These data were aggregated at the nine sites also characterised by the Hudak team, based on their 135 GPS points per site, in order to associate the Ottmar team field measures with SMA fractional cover estimates at the site level. Observed $v$. predicted measures of post-fire forest floor depth at these nine sites were significantly correlated $(\rho=0.87, P=0.0045)$, as was percentage consumption $(\rho=0.73, P=0.03)$.

\section{Discussion}

\section{Observed ground cover and consumption data}

When field sites were selected for post-fire sampling by the Hudak team, a BARC map was used to help guide site selection 
to try and ensure that sites covered the full range of burn severities: low, moderate and high. However, on initial examination of the ground-cover data, total remaining organic cover averaged $75 \%$ on high severity sites and ash and soil cover was only $24 \%$ (not shown). We compared these values with other publications and found that our 'high' severity sites were not as severely burned as other researchers had found in nearby areas on the same fires. Kasischke et al. (2008) describe their 'moderate' sites as having had a $30-50 \%$ reduction in total surface organic layer and having 100 to $200 \mathrm{~mm}$ of organic material (depth) left after the fire. Their 'severely' burned sites experienced an $80-100 \%$ reduction in total surface organic layer and had between $<10$ and $40 \mathrm{~mm}$ of organic material left after the fire. In an unrelated study, Epting et al. (2005) revised the CBI to reflect the combustion of the deep organic forest floor layers in Alaska boreal forests. A site was considered moderate severity if up to $50 \%$ of the duff layer was consumed in the fire and high severity if $75-100 \%$ was consumed - these classes are very similar values to those in Kasischke et al. (2008).

Four of our black spruce sites fit into these previously defined classes as 'moderate' severity, with $28-48 \%$ consumption (Table 1). The remaining five sites experienced $53-72 \%$ consumption and had less than $100 \mathrm{~mm}$ of organic forest floor remaining. These values indicate more severe burning than either Epting et al. (2005) or Kasischke et al. (2008) reported for 'moderate' severity, but significantly less consumption than either reported for 'high' or 'severe' burn severity. Thus, these black spruce sites seem to fit a 'moderately high' severity class, but not the upper-end of the burn severity spectrum (i.e. 'severe'). All six of our white spruce sites with consumption data experienced greater than $60 \%$ consumption (at least 'moderate' severity) and four sites had greater than $80 \%$ consumption (Table 1), which corresponds to a 'high' severity class, and less than $100 \mathrm{~mm}$ of organic material remaining after the fire. Although our sites did not capture the 'severe' end of the burnseverity spectrum, sorting them by percentage organic forest floor consumption indicated that they spanned the full range of low to moderate-high severity range.

A somewhat alternative concept that equates severity to depth of consumption instead of percentage consumption is supported by Alexander (1982) and Nguyen-Xuan et al. (2000). French et al. (2008) characterised high severity burns as those with at least 100 to $300 \mathrm{~mm}$ of forest floor consumption. All of our black spruce sites and three of the white spruce sites that we post-hoc labelled as 'moderately high' severity had greater than $100 \mathrm{~mm}$ consumption.

\section{Relationship between post-fire ground cover and forest floor depth and consumption}

Pre- and post-fire forest floor depths were significantly correlated with most of the ground cover fractions, as was percentage consumption, but depth of consumption was not (Table 2). Thus, depth of consumption seems to be a less reliable metric of burn severity than percentage consumption, a conclusion supported by the results in Fig. 7. Sites with deeper pre-fire forest floor layers experienced low to moderate fire effects. Many other researchers including de Groot et al. (2009), Harden et al. (2006), Kasischke and Johnstone (2005) and Ottmar and
Sandberg (2003) concur, leading us to conclude that pre-fire forest floor depth is highly influential in terms of predicting potential consumption, which in turn affects the amount of mineral soil exposure after the fire. This indicates that pre-fire forest floor depth or the continuity of a live moss layer may be used to predict areas that will, or will not, experience severe fire and significant consumption.

Fire in the boreal forest is generally carried by the forest floor, and is highly dependent on the moisture content of the surface material (Frandsen 1997; Kasischke et al. 2008). In the present analysis, fuel moisture data were only available at the nine sites established by the Ottmar team. Post-fire duff moisture was highly correlated with percentage forest floor consumption $(\rho=-0.95, P<0.001)$. Deeper forest floor layers are generally wetter and cooler, especially closer to the soil or permafrost (Miyanishi and Johnson 2002), as is more typical of black spruce than white spruce-hardwood forest. Deep forest floor layers can take many years to accumulate after a fire or other disturbance (Fenton et al. 2005); thus the likelihood of a high severity reburn is low if most of the forest floor was consumed in the original fire. Fenton et al. (2005) found that the depth of forest floor accumulation was most dependent on two variables: time since fire and burn severity. After a low severity burn, the forest floor remained somewhat constant at $400-600 \mathrm{~mm}$ depth for 250 years after the fire, with a spike to $1600 \mathrm{~mm} 350$ years after fire. On high severity burns, the forest floor increased in depth by 100-200 mm every 100 years, with a maximum of 1000-mm depth after 350 years. On mature black spruce stands, Kasischke and Johnstone (2005) also found that time since burning was a significant predictor of organic layer depth, and that a maximum depth was reached at $\sim 200$ years. Results presented here along with past studies confirm that pre-fire total forest floor depth is an important determinant of post-fire effects.

\section{Relationship between spectral unmixing results and post-fire ground cover}

The green SMA fraction had the strongest correlation with the cover fractions measured on the ground (Table 3), validating the same finding by Hudak et al. (2007) using Landsat imagery. Charred moss, ash and soil and rock SMA cover fractions were also positively correlated with their counterparts on the ground. These results justify the use of fractional cover maps to estimate ground-cover conditions in areas outside of the field data collection sites (Figs 6,8). Additional red-green-blue colour combinations of the ground cover types can be used to illustrate the high heterogeneity of the forest floor across the entire area. There were virtually no pure pixels; rather, a combination of green moss and NPV moss, or NPV moss and charred NPV moss, or a combination of all three were seen in the images. When ground-cover types are combined in a colour composite, the dominant cover type determines the colour of the pixel. It should be noted that the spatially nested sampling of green, NPV and charred organic ground cover fractions at each site was not matched by a comparably intensive assessment of overstorey green, brown (scorched) and black (charred) cover fractions, which the Hudak team estimated only once, at the centre of each site. Thus, we lacked sufficient data to quantify the degree to which variable tree canopy condition across a field site affects 


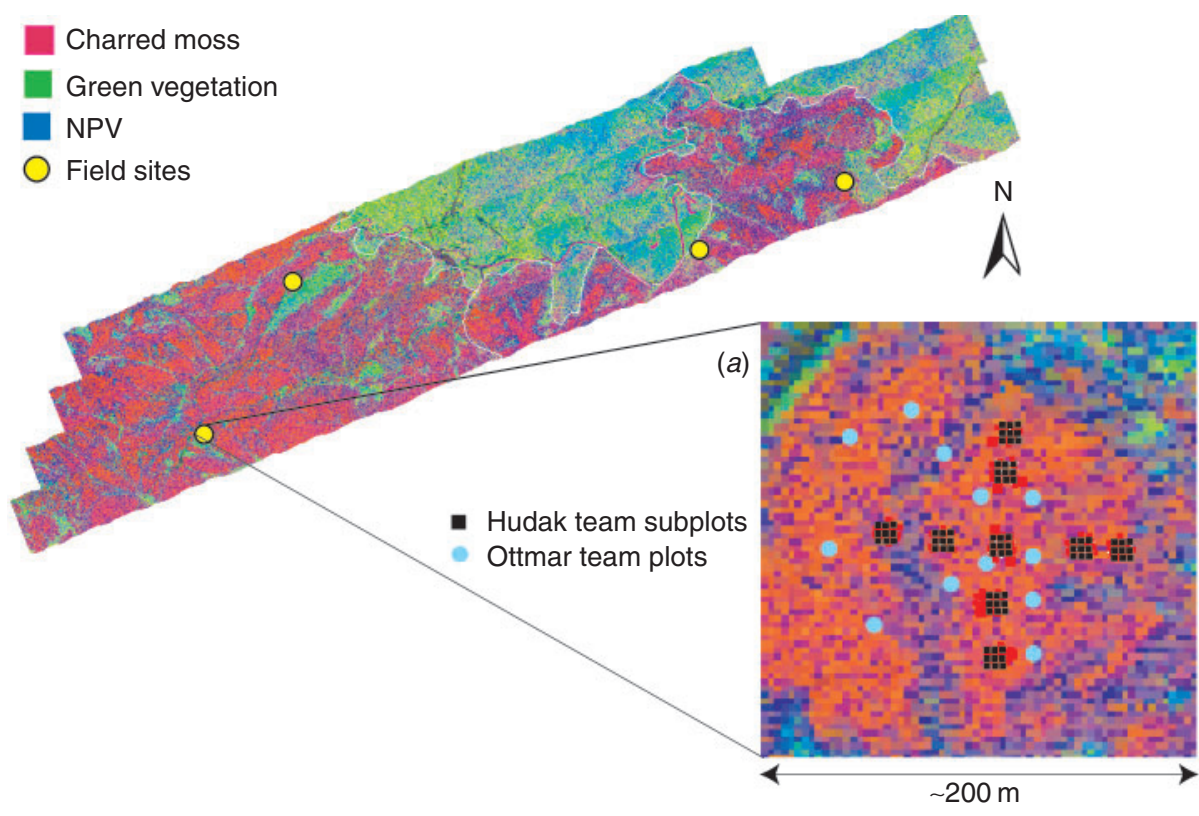

(b)

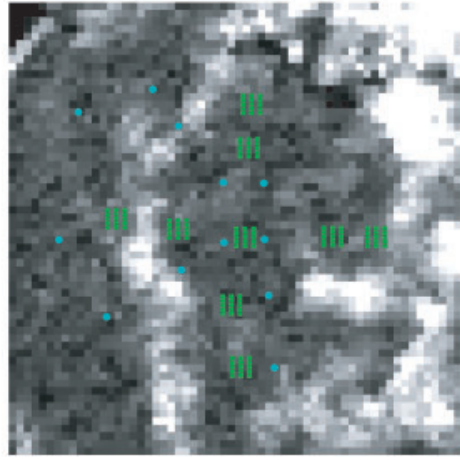

(c)

- Hudak team subplots - Ottmar team plots

Post-fire depth $250 \mathrm{~mm}$ $80 \%$
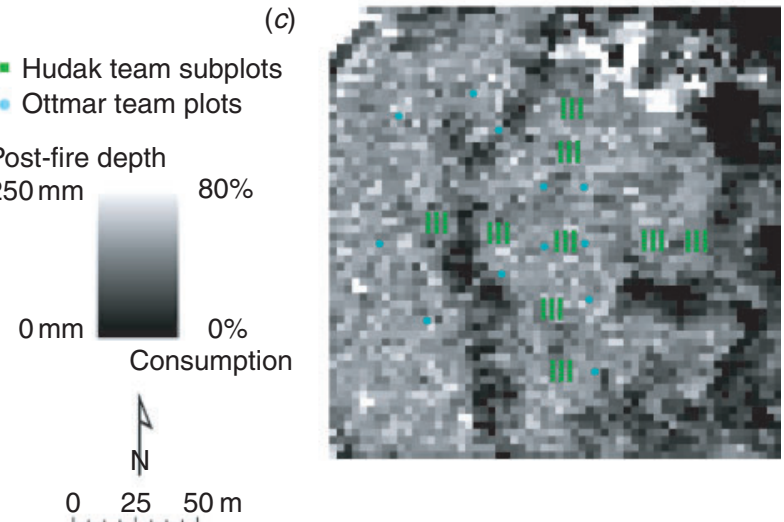

Fig. 8. A red-green-blue (RGB) colour composite of the Chicken and Wall Street Fire imagery: red represents charred moss, green represents green vegetation and blue represents non-photosynthetic vegetation (NPV). Subset images of the Chicken 1 site show: $(a)$ the fine-scale RGB image; $(b)$ post-fire forest floor depth; and (c) percentage forest floor consumption. The Taylor Highway runs diagonally across the north-west corner.

the SMA fractional cover estimates. The fact that the green moss SMA fraction figured so prominently (Tables 3, 4), compared with the relatively minor green cover fraction estimated on the ground (Fig. 4), supports earlier research findings that this overstorey contribution to the mixed pixel reflectance signal is important (Hudak et al. 2007).

Besides moss and other surface organic material, there was little else present in terms of ground cover on these sites when we sampled them within 6-34 days after burning. Our results affirm that soil, ash and shallow post-fire forest floor depths are generally found together in areas that experienced more severe fire. Even though our black spruce and white spruce sites experienced different degrees of consumption (Table 1; Fig. 5), the remaining ground-cover components did not distinguish between black and white spruce sites after the fire (Fig. 4). Thus, the SMA results are equally applicable to both the black and white spruce forest types. On our field sites, the exposure of mineral soil coupled with the lack of uncharred vegetation and some presence of ash indicated a considerable degree of combustion. Soil and ash ground-cover fractions that were more than negligible served as important indicators of higher burn severity on the ground, yet comprised a minor proportion of the ground cover on our moderate-high burn-severity sites (Fig. 4). We expect that if our field sites had included severely burned sites where most of the organic layer was consumed, we would have found a greater percentage of exposed soil and ash on the ground.

This study was part of a larger research project that aimed to define quantitative indicators of burn severity that were mappable, scalable from field to remotely sensed imagery and, most importantly, consistent across vegetation types. Robichaud et al. (2007) used a partial spectral unmixing 
algorithm with hyperspectral imagery to determine post-fire green and scorched vegetation, soil and ash on the 2002 Hayman Fire in Colorado. They found that the combination of exposed soil and ash were mapped in the areas of highest soil burn severity and low or moderate conditions were indicated by green or scorched vegetation respectively. Lewis et al. (2007) used similar methods on the 2003 Simi and Old wildfires in southern California and found that exposed mineral soil and lack of organic ground cover indicated the most severe fire effects on the soil surface and an increased potential for hydrologic response. Lentile et al. (2007a) found that in large severe wildfires (in Montana, California and Alaska), there are generally extensive areas (and microsites) where significant organic material remains to protect the soil. In erosion-prone ecosystems (such as Montana and California), this organic cover protects the soil and helps vegetation recover. In Alaska, organic cover hinders tree recruitment, but protects the underlying soil from warming and potential thaw. Thus, even across the range of these ecosystems, it is generally exposed soil (inorganic cover) that indicates higher burn severity and organic cover that indicates lower burn severity (Tables 3,4 ).

\section{Relationship between remotely sensed fractional cover and forest floor consumption}

The variables that appeared to best indicate burn severity at either end of the spectrum were green moss (low) or soil and ash (high). However, the contribution of the green moss, ash, and soil and rock fractions to the mixed-pixel signature in this postfire boreal forest landscape was minor compared with the NPV fraction, most of which was charred (Fig. 4). Indeed, only the three SMA organic fractions were selected as significant predictor variables in the spatial simultaneous autoregressive linear models predicting post-fire forest floor depth and percentage forest floor consumption (Table 4).

The spatial autoregression models were used to predict postfire forest floor depth and percentage forest floor consumption; Fig. 8 portrays the fine-scale pattern in these forest-floor measures at one moderate-high severity site on the Chicken Fire (Table 1) and illustrates the potential for mapping remaining forest floor depth and percentage consumption from hyperspectral imagery. Fig. $8 a-c$ shows a close-up of the Chicken 1 site to illustrate the fine-scale variation and the Hudak and Ottmar team sample plot configurations. Fig. $8 b$ illustrates predicted post-fire forest floor depth and Fig. $8 \mathrm{c}$ predicts forest floor consumption (\%). Areas with more charred moss (red, Fig. $8 a$ ) have shallower forest floor depth (dark grey, Fig. 8b) due to greater percentage consumption (light grey, Fig. 8c). Within the 100-m-radius area encompassing the Hudak and Ottmar team plots, post-fire forest floor depth varies from 40 to $130 \mathrm{~mm}($ mean $=83 \mathrm{~mm}$, s.d. $=26 \mathrm{~mm})$ and forest floor consumption varies from 35 to $70 \%$ (mean $=52 \%$, s.d. $=10 \%$ ).

Considering the depth of forest floor that must be consumed to produce ash and expose soil (greater than $100 \mathrm{~mm}$ on most of our sites), it is not surprising that little ash was mapped by SMA or measured on the ground. However, ash can still be regarded as an important indicator of high severity fire effects. White ash is a sign of complete surface vegetation combustion and is most prevalent when burn severity is high (Rogan and Franklin 2001; Landmann 2003; Smith and Hudak 2005; Smith et al. 2005;
Kokaly et al. 2007). Both Landmann (2003) and Smith et al. (2007) used spectral mixture models with Landsat data to map ash and combustion completeness and found ash abundance increased with increasing vegetation combustion. This holds true in a boreal forest setting, requiring even more vegetative combustion to result in a measurable amount of ash because of the depth of forest floor material that must burn to achieve complete combustion.

Forest fires can have both immediate and long-term implications for ecological and physical processes in the boreal forest through the amount of forest floor consumption (Kasischke et al. 2008). For example, post-fire succession is influenced by amount of bare soil exposed following fire (Johnstone and Kasischke 2005; Greene et al. 2007; Johnstone et al. 2008). Consumption increases the depth of the soil active layer (the layer of soil between the permafrost and the soil surface that thaws during the summer) (Dyrness 1982; Swanson 1996; O'Neill et al. 2002; Harden et al. 2006) as well as types and quantities of nutrients released following fire and soil moisture, which all have an effect on plant growth, species composition and post-fire succession (Kane et al. 2005; Kasischke et al. 2007). Absolute consumption can have an effect on the atmosphere through carbon emissions, on the vegetation community through seedling recruitment and survival, and on long-term changes in soil moisture and temperature (Kasischke et al. 2008). Fire also temporarily reverses the role of the boreal forest as a carbon sink (O'Neill et al. 2003), both from the direct emissions and from the rate of decay of the forest floor layers when warming occurs. Further research is warranted to more accurately predict the effect of fire and organic layer consumption on boreal forest carbon balance.

\section{Achieving fire science objectives within rapid-response research operational constraints}

The primary objective of any rapid-response research team is safety (Lentile et al. 2007b). Research objectives are necessarily subsidiary. We would have preferred to conduct a more statistically powerful analysis if the Hudak and Ottmar teams had collected field data at coincident plots rather than as we did at overlapping sites. However, this would have required not only more time on site but that the Hudak team co-locate their plots with the Ottmar team's plots, causing trampling and adversely affecting their post-fire forest floor depth and consumption measurements. Moreover, the Ottmar team's plots were not as equitably distributed across the full range of burn severity conditions, or between sites (Table 1). The Ottmar and Hood teams' objectives were to establish as many plots as possible, in advance of the wildfire front, when the fire weather, fuel conditions, access, safety and other operational constraints of working in an active wildfire incident made it advantageous to do so, not knowing whether the plot would burn or how severely. The Hudak team could more equitably distribute field sites across the full range of burn severities observed in the post-fire landscape and could afford to spend more time carefully geolocating their plots for the purpose of image validation. Even though the objectives and sampling designs of the Ottmar and Hudak teams were not completely compatible, significant data overlaps occurred and were considered complimentary. 


\section{Conclusion}

This study was a unique collaboration among three rapidresponse research teams that resulted in spatially explicit, quantified comparisons of the boreal forest floor before and immediately following wildfire. Forest floor consumption was measured via assessment of pre- and post-fire forest floor depth and SMA was used with high-resolution hyperspectral imagery to predict and map post-fire forest floor depth and consumption. These predictive models were corroborated by significant correlations between the depth of forest floor and organic and inorganic post-fire ground-cover fractions and validated with independent data. As expected, sites with deeper pre-fire forest floor were less severely burned by fire, resulting in lower consumption and higher residual organic ground cover compared with more severely burned areas. Areas with low forest floor consumption were characterised by extensive green and NPV cover. Areas with substantial consumption (greater than $100 \mathrm{~mm}$ ) were characterised by charred vegetation, ash and exposed mineral soil cover. The fractional covers of these variables can be readily assessed in the field and remotely. As they are likely correlated with vegetation response to fire and with other ecosystem effects of fires, and because they are continuous, mappable and scalable, they jointly can be used as indicators of burn severity. Of all of the variables that were mapped with SMA, green moss was the most accurate compared with field data, and had the strongest correlation with forest floor depth and percentage forest floor consumption. A map of a continuous layer of green moss may be used to predict areas that will likely not experience severe fire effects in future fires.

The ability to spatially predict the depth or degree of consumption at a fine scale with hyperspectral data is an important development in the field of boreal fire ecology. These methods were established on sites that experienced low to moderately high severity fire effects and should be tested under more extreme forest floor consumption conditions before they are confidently applied to future wildfires in the boreal forest As a consequence of global climate change, fires in the boreal region are predicted to be larger, have higher burn severity and occur more frequently than in the past (Flannigan and Van Wagner 1991; Overpeck et al. 1991; Kasischke et al. 1995a; Rupp et al. 2000; Kasischke and Turetsky 2006). Owing to these changes, mapping fire effects and predicting ecological effects will likely be the focus of significant research in the coming years.

\section{Acknowledgements}

This project was supported by the USDA Forest Service and Department of Interior Joint Fire Science Program (JFSP) grants (03-2-1-02 and 03-S-01). We are very grateful to the JFSP for providing funding and support throughout the course of this project. This research was also supported in part by funds provided by the Rocky Mountain Research Station, USDA Forest Service and by the University of Idaho. We thank the Alaska Fire Service for their logistical support during our field sampling campaign. Many people helped with field data collection and analysis including: Stephanie Jenkins, K. C. Murdock, Scott MacDonald, Mike Bobbitt, Carter Stone, Helen Smith, Ed Mathews, Cassandra Koerner and Nat Johnson. Stephen Gulick and Rulon Simmons helped with field spectra collection, and Denise Laes helped with the pre-processing of the hyperspectral imagery.

\section{References}

Adams JB, Smith MO, Johnson PE (1986) Spectral mixture modeling: a new analysis of rock and soil types at the Viking Lander 1 site Journal of Geophysical Research 91(B8), 8098-8112. doi:10.1029/ JB091IB08P08098

Alexander ME (1982) Calculating and interpreting forest fire intensities. Canadian Journal of Botany 60, 349-357. doi:10.1139/B82-048

Boardman JW (1998) Post-ATREM polishing of AVIRIS apparent reflectance data using EFFORT: a lesson in accuracy versus precision. In 'Proceedings of the Seventh Annual JPL Airborne Earth Science Workshop', 12-14 January 1998, Pasadena, CA. (Ed. RO Green) NASA Jet Propulsion Laboratory publication 97-21, vol. 1. (Pasadena, CA)

Cahoon DR, Jr, Stocks BJ, Levine JS, Cofer WR, III, Pierson JM (1994) Satellite analysis of the severe 1987 forest fires in northern China and south-east Siberia. Journal of Geophysical Research 99, 18 627-18 638 doi:10.1029/94JD01024

Conard SG, Sukhinin AI, Stocks BJ, Cahoon DR, Davidenko EP, Ivanova GA (2002) Determining effects of area burned and fire severity on carbon cycling and emissions in Siberia. Climatic Change 55, 197-211. doi:10.1023/A:1020207710195

Cracknell AP (1998) Synergy in remote sensing: what's in a pixel? International Journal of Remote Sensing 19(11), 2025-2047. doi:10.1080 014311698214848

Cressie NAC (1993) 'Statistics for Spatial Data.' (Wiley: New York)

de Groot WJ, Pritchard JM, Lynham TJ (2009) Forest floor fuel consumption and carbon emissions in Canadian boreal forest fires. Canadian Journal of Forest Research 39(2), 367-382. doi:10.1139/X08-192

Duffy PA, Epting J, Graham JM, Rupp TS, McGuire AD (2007) Analysis of Alaskan burn severity patterns using remotely sensed data. International Journal of Wildland Fire 16, 277-284. doi:10.1071/WF06034

Dyrness CT (1982) Control of depth to permafrost and soil temperature by the forest floor in black spruce/feathermoss communities. USDA Fores Service, Pacific Northwest Research Station, Research Paper PNW-396. (Portland, OR)

Dyrness CT, Norum RA (1983) The effects of experimental fires on black spruce forest floors in interior Alaska. Canadian Journal of Forest Research 13, 879-893. doi:10.1139/X83-118

Epting J, Verbyla D, Sorbel B (2005) Evaluation of remotely sensed indices for assessing burn severity in interior Alaska using Landsat TM and ETM+. Remote Sensing of Environment 96, 328-339. doi:10.1016/ J.RSE.2005.03.002

Fenton N, Lecomte N, Legare S, Bergeron Y (2005) Paludification in black spruce (Picea mariana) forests of eastern Canada: potential factors and management implications. Forest Ecology and Management 213(1-3), 151-159. doi:10.1016/J.FORECO.2005.03.017

Flannigan MD, Van Wagner CE (1991) Climate change and wildfire in Canada. Canadian Journal of Forest Research 21, 66-72. doi:10.1139/ X91-010

Flannigan MD, Stocks BJ, Wotton MB (2000) Climate change and forest fires. The Science of the Total Environment 262, 221-229. doi:10.1016/ S0048-9697(00)00524-6

Flannigan MD, Logan KA, Amiro BD, Skinner WR, Stocks BJ (2005) Future area burned in Canada. Climatic Change 72, 1-16. doi:10.1007 S10584-005-5935-Y

Foote MJ (1983) Classification, description, and dynamics of plant communities after fire in the taiga of interior Alaska. USDA Fores Service, Pacific Northwest Research Station, Research Paper PNW-307. (Portland, OR)

Frandsen WH (1997) Ignition probability of organic soils. Canadian Journa of Forest Research 27, 1471-1477. doi:10.1139/CJFR-27-9-1471

French NHF, Kasischke ES, Johnson RD, Bourgeau-Chavez LL, Frick AL, Ustin SL (1996) Estimating fire-related carbon flux in Alaskan boreal forests using multisensor remote sensing data. In 'Biomass Burning and 
Global Change'. (Ed. JS Levine) pp. 808-826. (MIT Press: Cambridge, MA)

French NHF, Kasischke ES, Hall RJ, Murphy KA, Verbyla DL, Hoy EE, Allen JL (2008) Using Landsat data to assess fire and burn severity in the North American boreal forest region: an overview and summary of results. International Journal of Wildland Fire 17, 443-462. doi:10.1071/WF08007

Gao BC, Heidebrecht KB, Goetz AFH (1993) Derivation of scaled surface reflectances from AVIRIS data. Remote Sensing of Environment 44, 165-178. doi:10.1016/0034-4257(93)90014-O

Gillett NP, Weaver AJ, Zwiers FW, Flannigan MD (2004) Detecting the effect of climate change on Canadian forest fires. Geophysical Research Letters 31, L18211. doi:10.1029/2004GL020876

Gould WA, Hudak AT, González G, Hollingsworth T, Hollingsworth J (2008) Forest structure and downed woody debris in boreal, temperate, and tropical forest fragments. Ambio 37(7), 577-587. doi:10.1579/00447447-37.7.577

Greene DF, Macdonald SE, Haeussler S, Domenicano S, Noël J, Jayen K, Charron I, Gauthier S, Hunt S, Gielau ET, Bergeron Y, Swift L (2007) The reduction of organic-layer depth by wildfire in the North American boreal forest and its effect on tree recruitment by seed. Canadian Journal of Forest Research 37, 1012-1023. doi:10.1139/X06-245

Haining R (1990) 'Spatial Data Analysis in the Social and Environmental Sciences.' (Cambridge University Press: Cambridge, UK)

Harden JW, Trumbore SE, Stocks BJ, Hirsch A, Gower ST, O’Neill KP, Kasischke ES (2000) The role of fire in the boreal carbon budget. Global Change Biology 6(S1), 174-184. doi:10.1046/J.1365-2486. 2000.06019.X

Harden JW, Manies KL, Neff JC, Turetsky MR (2006) Effects of wildfire and permafrost on soil organic matter and soil climate in interior Alaska. Global Change Biology 12, 2391-2403. doi:10.1111/J.1365-2486.2006. 01255.X

Hoy EE, French NHF, Turetsky MR, Trigg SN, Kasischke ES (2008) Evaluating the potential of Landsat TM/ETM+ imagery for assessing fire severity in Alaskan black spruce forests. International Journal of Wildland Fire 17, 500-514. doi:10.1071/WF08107

Huang C, Townshend JRG, Liang S, Kalluri SNV, DeFries RS (2002) Impact of a sensor's point spread function on land cover characterization. Remote Sensing of Environment 80(2), 203-212. doi:10.1016/ S0034-4257(01)00298-X

Hudak AT, Brockett BH (2004) Mapping fire scars in a southern African savannah using Landsat imagery. International Journal of Remote Sensing 25(16), 3231-3243. doi:10.1080/01431160310001632666

Hudak AT, Morgan P, Bobbitt MJ, Smith AMS, Lewis SA, Lentile LB, Robichaud PR, Clark JT, McKinley RA (2007) The relationship of multispectral satellite imagery to immediate fire effects. Fire Ecology 3(1), 64-90. doi:10.4996/FIREECOLOGY.0301064

Johnstone J, Chapin FS, III (2006) Effects of soil burn severity on patterns of post-fire tree recruitment in boreal forests. Ecosystems 9, 14-31. doi: $10.1007 /$ S10021-004-0042-X

Johnstone J, Kasischke ES (2005) Stand-level effects of soil burn severity on post-fire regeneration in a recently burned black spruce forest. Canadian Journal of Forest Research 35, 2151-2163. doi:10.1139/X05-087

Johnstone JF, Hollingsworth TN, Chapin FS, III (2008) A key for predicting successional trajectories in black spruce stands of interior Alaska. USDA Forest Service, Pacific Northwest Research Station, General Technical Report PNW-GTR-767. (Portland, OR)

Kane ES, Valentine DW, Schuur EAG, Dutta K (2005) Soil carbon stabilization along climate and stand productivity gradients in black spruce forests of interior Alaska. Canadian Journal of Forest Research 35, 2118-2129. doi: $10.1139 / \mathrm{X} 05-093$

Kane ES, Kasischke ES, Valentine DW, Turetsky MR, McGuire AD (2007) Topographic influences on wildfire consumption of soil organic carbon in interior Alaska: implications for black carbon accumulation. Journal of Geophysical Research 112, G03017. doi:10.1029/2007JG000458

Kasischke ES, Johnstone JF (2005) Variation in post-fire organic layer thickness in a black spruce forest complex in interior Alaska and its effects on soil temperature and moisture. Canadian Journal of Forest Research 35, 2164-2177. doi:10.1139/X05-159

Kasischke ES, Turetsky MR (2006) Recent changes in fire regime across the North American boreal region - spatial and temporal patters of burning across Canada and Alaska. Geophysical Research Letters 33, L09703. doi:10.1029/2006GL025677

Kasischke ES, Christensen NL, Jr, Stocks BL (1995a) Fire, global warming, and the carbon balance of boreal forests. Ecological Applications 5(2), 437-451. doi:10.2307/1942034

Kasischke ES, French NHF, Borgeau-Chavex LL, Christensen NL, Jr (1995b) Estimating release of carbon from 1990 and 1991 forest fires in Alaska. Journal of Geophysical Research 100, 2941-2951. doi:10.1029/94JD02957

Kasischke ES, Bourgeau-Chavez LL, Johnstone JF (2007) Assessing spatial and temporal variations in surface soil moisture in fire-disturbed black spruce forests in interior Alaska using spaceborne synthetic aperture radar imagery - implications for post-fire tree recruitment. Remote Sensing of Environment 108, 42-58. doi:10.1016/J.RSE.2006.10.020

Kasischke ES, Turetsky MR, Ottmar RD, French NHF, Hoy EH, Kane ES (2008) Evaluation of the Composite Burn Index for assessing fire severity in Alaska black spruce forests. International Journal of Wildland Fire 17, 515-526. doi:10.1071/WF08002

Key CH, Benson NC (2005) Landscape assessment: remote sensing of severity, the Normalized Burn Ratio, and ground measure of severity, the Composite Burn Index. In 'FIREMON: Fire Effects Monitoring and Inventory System'. (Eds DC Lutes, RE Keane, JF Caratti, CH Key, NC Benson, S Sutherland, LJ Gangi) USDA Forest Service, Rocky Mountain Research Station, General Technical Report RMRS-GTR-164-CD: LA1-51. (Ogden, UT)

Kokaly RF, Rockwell BW, Haire SL, King TVV (2007) Characterization of post-fire surface cover, soils, and burn severity at the Cerro Grande Fire, New Mexico, using hyperspectral and multispectral remote sensing. Remote Sensing of Environment 106(3), 305-325. doi:10.1016/J.RSE. 2006.08 .006

Kushida K, Isaev AP, Takao G, Maximov TC, Fukada M (2007) Remote sensing of total and surface burn ratios following a wildfire in East Siberia using $30 \mathrm{~m}-1 \mathrm{~km}-$ resolution images. Eurasian Journal of Forest Research 10-1, 105-114.

Landmann T (2003) Characterizing sub-pixel Landsat ETM+ fire severity on experimental fires in the Kruger National Park, South Africa. South African Journal of Science 99, 357-360.

Lentile LB, Morgan P, Hudak AT, Bobbitt MJ, Lewis SA, Smith AMS, Robichaud PR (2007a) Post-fire burn severity and vegetation response following eight large wildfires across the western United States. Fire Ecology 3(1), 91-108. doi:10.4996/FIREECOLOGY.0301091

Lentile L, Morgan P, Hardy C, Hudak A, Means R, Ottmar R, Robichaud P, Kennedy Sutherland E, Szymokiak J, Way F, Fites-Kaufmann J, Lewis S, Mathews E, Shovic H, Ryan K (2007b) Value and challenges of conducting rapid response research on wildland fires. USDA Forest Service, Rocky Mountain Research Station, General Technical Report RMRS-GTR-193. (Fort Collins, CO)

Lewis SA, Lentile LB, Hudak AT, Robichaud PR, Morgan P, Bobbitt MJ (2007) Mapping ground cover using hyperspectral remote sensing after the 2003 Simi and Old wildfires in southern California. Fire Ecology 3(1), 109-128. doi:10.4996/FIREECOLOGY.0301109

Michalek JL, French NHF, Kasischke ES, Johnson RD, Colwell JE (2000) Using Landsat TM data to estimate carbon release from burned biomass in an Alaskan spruce forest complex. International Journal of Remote Sensing 21(2), 323-338. doi:10.1080/014311600210858 
Miyanishi K, Johnson EA (2002) Process and patterns of duff consumption in the mixedwood boreal forest. Canadian Journal of Forest Research 32, 1285-1295. doi:10.1139/X02-051

Murphy KA, Reynolds JH, Koltun JM (2008) Evaluating the ability of the differenced Normalized Burn Ratio (dNBR) to predict ecologically significant burn severity in Alaskan boreal forests. International Journal of Wildland Fire 17, 490-499. doi:10.1071/WF08050

Murphy PJ, Mudd JP, Stocks BJ, Kasischke ES, Barry D, Alexander ME, French NF (2000) Historical fire records in the North American boreal forest. In 'Fire, Climate Change, and Carbon Cycling in the Boreal Forest'. (Eds ES Kasischke, BJ Stock) pp. 274-288. (Springer-Verlag: New York)

Nguyen-Xuan T, Bergeron Y, Simard D, Fyles JW, Pare D (2000) The importance of forest floor disturbance in the early regeneration patterns of the boreal forest of western central Quebec: a wildfire versus logging comparison. Canadian Journal of Forest Research 30, 1353-1364. doi:10.1139/CJFR-30-9-1353

O'Donnell JA, Turetsky MR, Harden JW, Manies KL, Pruett LE, Shetler G, Neff JC (2009) Interactive effects of fire, soil climate, and moss on $\mathrm{CO}_{2}$ fluxes in black spruce ecosystems of interior Alaska. Ecosystems $\mathbf{1 2}$ 57-72. doi:10.1007/S10021-008-9206-4

O’Neill KP, Kasischke ES, Richter DD (2002) Environmental controls on soil $\mathrm{CO}_{2}$ flux following fire in black spruce, white spruce, and aspen stands of interior Alaska. Canadian Journal of Forest Research 32 1525-1541. doi:10.1139/X02-077

O’Neill KP, Kasischke ES, Richter DD (2003) Seasonal and decadal patterns of soil carbon uptake and emission along an age sequence of burned black spruce stands in interior Alaska. Journal of Geophysical Research 108(D1), 8155. doi:10.1029/2001JD000443

Ottmar RD, Sandberg DV (2003) Predicting forest floor consumption from wildland fire in boreal forests of Alaska - preliminary results. In 'Proceedings from Fire Conference 2000: the First National Congress on Fire Ecology, Prevention, and Management', 27 November1 December 2000, San Diego, CA. (Eds KEM Galley, RC Klinger, NG Sugihara) pp. 218-224. (Tall Timbers Research Station: Tallahassee, FL)

Overpeck JT, Bartlein PJ, Webb T, III (1991) Potential magnitude of future vegetation change in eastern North America: comparisons with the past. Science 254, 692-695. doi:10.1126/SCIENCE.254.5032.692

R Development Core Team (2004) R: A language and environment for statistical computing. (R Foundation for Statistical Computing: Vienna, Austria) Available at http://www.R-project.org [Verified 12 June 2009]

Richards JA, Jia X (1999) Interpretation of hyperspectral image data. In 'Remote Sensing Digital Image Analysis: an Introduction'. pp. 313-337. (Springer: New York)

Roberts DA, Smith MO, Adams JB (1993) Green vegetation, nonphotosynthetic vegetation and soils in AVIRIS data. Remote Sensing of Environment 44, 255-269. doi:10.1016/0034-4257(93)90020-X

Robichaud PR, Lewis SA, Laes DYM, Hudak AT, Kokaly RF, Zamudio JA (2007) Post-fire soil burn severity mapping with hyperspectral image unmixing. Remote Sensing of Environment 108, 467-480. doi:10.1016/ J.RSE.2006.11.027

Rogan J, Franklin J (2001) Mapping wildfire burn severity in southern California forests and shrublands using Enhanced Thematic Mapper imagery. Geocarto International 16(4), 91-106. doi:10.1080/ 10106040108542218

RSAC (2005) Remote Sensing Applications Center Burned Area Emergency Response (BAER) imagery support. USDA Forest Service,
Remote Sensing Applications Center. (Salt Lake City, UT) Available at http://www.fs.fed.us/eng/rsac/baer/ [Verified 17 November 2008]

Rupp TS, Chapin FS, III, Starfield AM (2000) Response of subarctic vegetation to transient climate change on the Seward Peninsula in north-west Alaska. Global Change Biology 6(5), 541-555. doi:10.1046/ J.1365-2486.2000.00337.X

Sandberg DV, Ottmar RD, Peterson JL, Core J (2002) Wildland fire on ecosystems: effects of fire on air. USDA Forest Service, Rocky Mountain Research Station, General Technical Report RMRS-GTR-42-Vol. 5. (Ogden, UT)

SAS Institute Inc. (2002) 'SAS 9.1.3 Service Pack 4.' (Cary, NC)

Schuur EAG, Bockheim J, Canadell J, Euskirchen E, Field CB, Goryachkin SV, Hagemann S, Kuhry P, Lafleur P, Lee H, Mazhitova G, Nelson FE, Rinke A, Romanovsky VE, Shiklomanov N, Tarnocai C, Venevsky S, Vogel JG, Zimov SA (2008) Vulnerability of permafrost carbon to climate change: implications for the global carbon cycle. BioScience 58(8), 701-714. doi:10.1641/B580807

Shetler G, Turetsky MR, Kane E, Kasischke E (2008) Sphagnum mosses limit total carbon consumption in Alaskan black spruce forests. Canadian Journal of Forest Research 38, 2328-2336. doi:10.1139/X08-057

Smith AMS, Hudak AT (2005) Estimating combustion of large downed woody debris from residual white ash. International Journal of Wildland Fire 14, 245-248. doi:10.1071/WF03052

Smith AMS, Wooster MJ, Drake NA, Dipotso FM, Falkowski MJ, Hudak AT (2005) Testing the potential of multi-spectral remote sensing for retrospectively estimating fire severity in African savannahs. Remote Sensing of Environment 97, 92-115. doi:10.1016/J.RSE.2005.04.014

Smith AMS, Lentile LB, Hudak AT, Morgan P (2007) Evaluation of linear spectral unmixing and $\Delta \mathrm{NBR}$ for predicting post-fire recovery in a North American ponderosa pine forest. International Journal of Remote Sensing 28(22), 5159-5166. doi:10.1080/01431160701395161

Soja AJ, Tchebakova NM, French NHF, Flannigan MD, Shugart HH, Stocks BJ, Sukhinin AI, Parfenova EI, Chapin FS, III, Stackouse PW, Jr (2007) Climate-induced boreal forest change: predictions versus current observations. Global and Planetary Climate Change 56, 274-296. doi:10.1016/J.GLOPLACHA.2006.07.028

Stocks BJ (1991) The extent and impact of forest fires in northern circumpolar countries. In 'Global Biomass Burning: Atmospheric, Climatic, and Biospheric Implications’. (Ed. JS Levine) pp. 197-202. (MIT Press: Cambridge, MA)

Swanson DK (1996) Susceptibility of permafrost soils to deep thaw after forest fires in interior Alaska, USA, and some ecologic implications. Arctic and Alpine Research 28, 217-227. doi:10.2307/1551763

Tan Z, Tieszen LL, Zhu Z, Liu S, Howard SM (2007) An estimate of carbon emissions from 2004 wildfires across Alaskan Yukon River Basin. Carbon Balance and Management 2, 12. doi:10.1186/1750-0680-2-12

Theseira MA, Thomas G, Taylor JC, Gemmell F, Varjo J (2003) Sensitivity of mixture modeling to end-member selection. International Journal of Remote Sensing 24(7), 1559-1575. doi:10.1080/01431160210146631

Townshend JRG, Huang C, Kalluri SNV, DeFries RS, Liang S (2000) Beware of per-pixel characterization of land cover. International Journal of Remote Sensing 21(4), 839-843. doi:10.1080/014311600210641

van Wagtendonk JW, Root RR, Key CH (2004) Comparison of AVIRIS and Landsat ETM + detection capabilities for burn severity. Remote Sensing of Environment 92, 397-408. doi:10.1016/J.RSE.2003.12.015

Manuscript received 21 July 2009, accepted 17 June 2010 